The Canadian Mineralogist

Vol. 40, pp. 85-101 (2002)

\title{
REACTION ZONES DEVELOPED BETWEEN CORUNDUM METAPELITE AND MARBLE, ALBORÁN SEA BASEMENT, WESTERN MEDITERRANEAN: ORIGIN AND PHASE RELATIONS
}

\author{
VICENTE LÓPEZ SÁNCHEZ-VIZCAÍNO \\ Departamento de Geología, Universidad de Jaén, Escuela Universitaria Politécnica de Linares, \\ C/ Alfonso X el Sabio 28, E-23700 Linares, Spain
}

JUAN IGNACIO SOTO $\$$

Instituto Andaluz de Ciencias de la Tierra \& Departamento de Geodinámica, C.S.I.C. - Universidad de Granada, Facultad de Ciencias, Campus Fuentenueva s/n, E-18071 Granada, Spain

\begin{abstract}
Several reaction-zones occur in the contact between impure calcite marble and corundum-bearing high-grade metapelite in the basement, Alborán Sea (site 976, ODP Leg 161, western Mediterranean). From the metapelite (corundum + biotite + anorthite + K-feldspar \pm garnet \pm sillimanite) to the marble (calcite + anorthite + biotite + amphibole + clinopyroxene), the sequence of mineral assemblages in these reaction zones is: corundum + hercynite + biotite + anorthite + K-feldspar (Zone I), hercynite + biotite + anorthite + K-feldspar (Zone II), biotite + garnet $\left(\mathrm{Grs}_{15-30}\right)+$ anorthite (Zone III), amphibole + biotite + garnet (Grs $25-$ 33) + anorthite + K-feldspar (Zone IV), anorthite + clinopyroxene (Zone V), and clinopyroxene + garnet (Grs $49-65)+$ anorthite (Zone VI). These reaction zones are interpreted as having developed by diffusion metasomatism of $\mathrm{Al}_{2} \mathrm{O}_{3}, \mathrm{CaO}$, and $\mathrm{SiO}_{2}$ between the marble and metapelite at $705<\mathrm{T}<730^{\circ} \mathrm{C}$ and $4.3<\mathrm{P}<5.1$ kbar. Corundum grew by a muscovite-breakdown reaction in the absence of quartz, at $\mathrm{T}>650^{\circ} \mathrm{C}$ and $\mathrm{P}<5 \mathrm{kbar}$. Phase-relation analysis with chemical potential projections $\left(\mu_{\mathrm{Al} 2 \mathrm{O} 3}-\mu_{\mathrm{SiO} 2}\right.$ $\left.-\mu_{\mathrm{CaO}}\right)$ is consistent with the observed sequence of reaction zones, the mineral assemblages, and the observed variation in the chemical composition of garnet, hercynite, and biotite among the different zones. The behavior of the three diffusing components is characterized by a slight mean variation in $\mu_{\mathrm{SiO} 2}$ and a strong variation in $\mu_{\mathrm{Al} 2 \mathrm{O} 3}$ and $\mu_{\mathrm{CaO}}$ between the metapelite and the calcite marble. In spite of this, strong gradients in chemical potential are deduced for $\mathrm{SiO}_{2}$ and $\mathrm{Al}_{2} \mathrm{O}_{3}$ through Zone III. In our opinion, this zone was formed under non-ideal conditions of diffusion owing to the heterogeneous character of the protolith, derived partly from a corundum metapelite and partly from a quartz-bearing metapelite.
\end{abstract}

Keywords: reaction zones, corundum, phase relations, diffusion, high-grade metamorphism, crustal extension, Alborán Sea, western Mediterranean.

\section{SOMMAIRE}

Plusieurs zones de réaction caractérisent le contact entre un marbre impur à calcite et une métapélite à corindon dans le socle de la mer Alborán (site de forage 976, campagne de forage ODP 161, mer Méditerranée occidentale). A partir de la métapélite (corindon + biotite + anorthite + feldspath potassique \pm grenat \pm sillimanite) jusqu' au marbre (calcite + anorthite + biotite + amphibole + clinopyroxène), voici la séquence d'assemblages de minéraux dans ces zones de réaction: corindon + hercynite + biotite + anorthite + feldspath potassique $($ Zone I), hercynite + biotite + anorthite + feldspath potassique $($ Zone II), biotite + grenat $\left(\mathrm{Grs}_{15-30}\right)+$ anorthite $\left(\right.$ Zone III), amphibole + biotite + grenat $\left(\mathrm{Grs}_{25-33}\right)+$ anorthite + feldspath potassique (Zone IV), anorthite + clinopyroxène (Zone V), and clinopyroxène + grenat (Grs $49-65)+$ anorthite (Zone VI). Ces zones de réaction résulteraient d'une métasomatose par diffusion de $\mathrm{Al}_{2} \mathrm{O}_{3}, \mathrm{CaO}$, et $\mathrm{SiO}_{2}$ entre le marbre et la métapélite à $705<\mathrm{T}<730^{\circ} \mathrm{C}$ et $4.3<\mathrm{P}<5.1 \mathrm{kbar}$. Le corindon serait le produit de la déstabilisation du corindon en l'absence du quartz à $\mathrm{T}>650^{\circ} \mathrm{C}, \mathrm{P}<5 \mathrm{kbar}$. Les relations de phases, analysées par projections de potentiels chimiques $\left(\mu_{\mathrm{Al} 2 \mathrm{O} 3}-\mu_{\mathrm{SiO} 2}-\mu_{\mathrm{CaO}}\right)$, concordent avec la séquence observée de zones de réaction, les assemblages de minéraux, et la variation observée en composition chimique du grenat, de l'hercynite et de la biotite parmi les zones. Le comportement des trois composants mobiles indique une légère variation en $\mu_{\mathrm{SiO} 2}$, en moyenne, et une forte variation en $\mu_{\mathrm{Al} 2 \mathrm{O} 3}$ et $\mu_{\mathrm{CaO}}$ entre la métapélite et le marbre à calcite. En revanche, il y aurait eu des gradients plus marqués en

$\S \quad$ E-mail addresses: vlopez@ujaen.es, jsoto@ugr.es 
potentiel chimique de $\mathrm{SiO}_{2}$ et $\mathrm{Al}_{2} \mathrm{O}_{3}$ à travers la Zone III. A notre avis, cette zone s'est formée sous conditions non-idéales de diffusion à cause de l'hétérogénéité du protolithe, dérivé aux dépens d'une métapélite à corindon et d'une métapélite quartzifère.

(Traduit par la Rédaction)

Mots-clés: zones de réaction, corindon, relations de phases, diffusion, degré de métamorphisme élevé, extension de la croûte, mer Alborán, Méditerranée occidentale.

\section{INTRODUCTION}

Diffusion in response to chemical potential gradients has proven to be an efficient process that explains the formation of reaction zones between adjacent rock types (e.g., Korzhinskii 1970, Brady 1977, Joesten 1977). Models applied to such reaction zones usually assume that ideal conditions take place during the diffusional process. Diffusing components are assumed to be in equilibrium at each point across the reaction band (Thompson 1959). This assumption allows one to simplify the problem and to predict the observed sequence of reaction bands due to continuous monotonic gradients in the chemical potential of the diffusing components (Brady 1977). Such monotonic gradients are, at least in part, the result of the application of these simple models to assemblages in which most minerals are considered to be pure phases with a fixed composition. Diffusion behavior is here complicated by several variables that alter the predicted ideal model. Such features include also irregular, inhomogeneous, additional or absent zones, textures indicative of incomplete reaction, and modal gradients (Dunkley et al. 1999).

In this paper, we describe zones of metasomatic reaction developed between a corundum-bearing (Al-saturated) metapelite and an impure calcite marble from the Alborán Sea basement, Western Mediterranean (drilled at site 976 of the Ocean Drilling Program, Leg 161). The observed sequence of mineral assemblages can be interpreted in both reaction zones in terms of combined diffusion of $\mathrm{CaO}, \mathrm{Al}_{2} \mathrm{O}_{3}$, and $\mathrm{SiO}_{2}$ across the reaction band. After determining the $\mathrm{P}-\mathrm{T}$ conditions of formation of these reaction zones, $725^{\circ} \mathrm{C}$ and $5 \mathrm{kbar}$, we have developed a thermodynamic model for their origin based on the variations in the chemical potential of $\mathrm{CaO}$ $\left(\mu_{\mathrm{CaO}}\right), \mathrm{Al}_{2} \mathrm{O}_{3}\left(\mu_{\mathrm{Al} 2 \mathrm{O} 3}\right)$, and $\mathrm{SiO}_{2}\left(\mu_{\mathrm{SiO} 2}\right)$. With the calculated projection of the phase diagram, we were able to model the observed sequence of mineral assemblages, together with the variation in the chemical composition of some minerals with a predictably complicated behavior (e.g., garnet and biotite).

\section{Geological Setting}

The Alborán Sea, in the Western Mediterranean, is an extensional basin of Tertiary age partly surrounded by an arcuate mountain chain comprising the Betic and Rif belts in southern Spain and Morocco, respectively. The Alborán Sea formed during the Miocene on the extended and thinned remains of the Internal Zones of these chains (e.g., Comas et al. 1992). The metamorphic basement of the Alborán Sea basin was drilled by ODP, Leg 161 at site 976 (Shipboard Scientific Party 1996) (Fig. 1a), and consists of high-grade quartz biotite - sillimanite - plagioclase schist with porphyroblasts of garnet and andalusite, and centimeter- to meterthick intercalations of calcite marble (Fig. 1b). The high-grade schist also contains millimetric to centimetric interlayers of corundum-bearing rocks lacking quartz and staurolite (where the composition is Al-rich), staurolite-bearing schist (where the composition is Ferich), and "fibrolite" and biotite-rich schist without plagioclase (Soto \& Platt 1999).

At Hole 976B (Fig. 1b), this sequence overlies banded pelitic gneiss with $\mathrm{K}$-feldspar, cordierite, and andalusite, with abundant migmatitic textures involving veins and foliation-parallel segregations of felsic material. Both the schist and gneiss are cut by peraluminous, leucogranitic dikes.

The schists and the gneisses show distinctive differences in their tectonometamorphic evolution (Soto \& Platt 1999). The high-grade schist experienced rapid decompression accompanied by heating (from $\sim 500^{\circ} \mathrm{C}$ at $10.5 \mathrm{kbar}$ to $650-700^{\circ} \mathrm{C}$ at $3-4 \mathrm{kbar}$ ), followed by cooling through $500-600^{\circ} \mathrm{C}$ at $2 \mathrm{kbar}$ or less. In the gneiss, partial melting occurred during a decompression $\mathrm{P}-\mathrm{T}$ path at $700-750^{\circ} \mathrm{C}$ from at least 6 to $3 \mathrm{kbar}$. Crystallization of anatectic melts took place during a subsequent isobaric cooling path $(\mathrm{P}<3 \mathrm{kbar})$ down to $\mathrm{T}$ $\sim 600^{\circ} \mathrm{C}$ (Soto et al. 1999). In both rock types, widespread disequilibrium and overstepping of metamorphic reactions are common features, suggesting rapid exhumation and cooling (average rate of cooling estimated to be $126^{\circ} \mathrm{C}$ per million years; Platt et al. 1998). This $\mathrm{P}-\mathrm{T}$ evolution is consistent with metamorphism in a late orogenic extensional basin, and suggests the complete removal of the lithospheric mantle beneath the extending region during the Neogene (Soto \& Platt 1999, Platt et al. 1998).

\section{Analytical Methods}

Mineral analysis was performed with a CAMEBAX SX-50 microprobe at the University of Granada. An acceleration voltage of $15 \mathrm{kV}$, a beam current of $20 \mathrm{nA}$, and a beam diameter of $8 \mu \mathrm{m}$ were used. Standards were simple synthetic oxides $\left(\mathrm{Al}_{2} \mathrm{O}_{3}, \mathrm{Fe}_{2} \mathrm{O}_{3}, \mathrm{Cr}_{2} \mathrm{O}_{3}, \mathrm{MnTiO}_{4}\right.$, $\mathrm{MgO}$ ), natural silicates (albite, orthoclase, and wollas- 
(a)

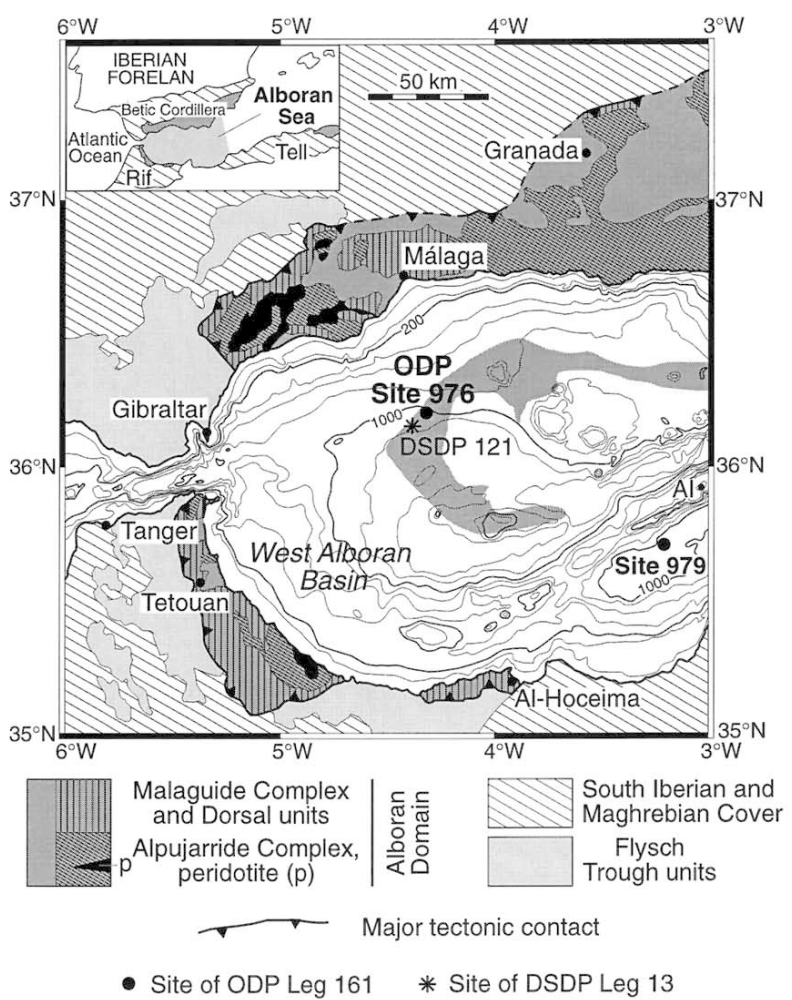

(b)

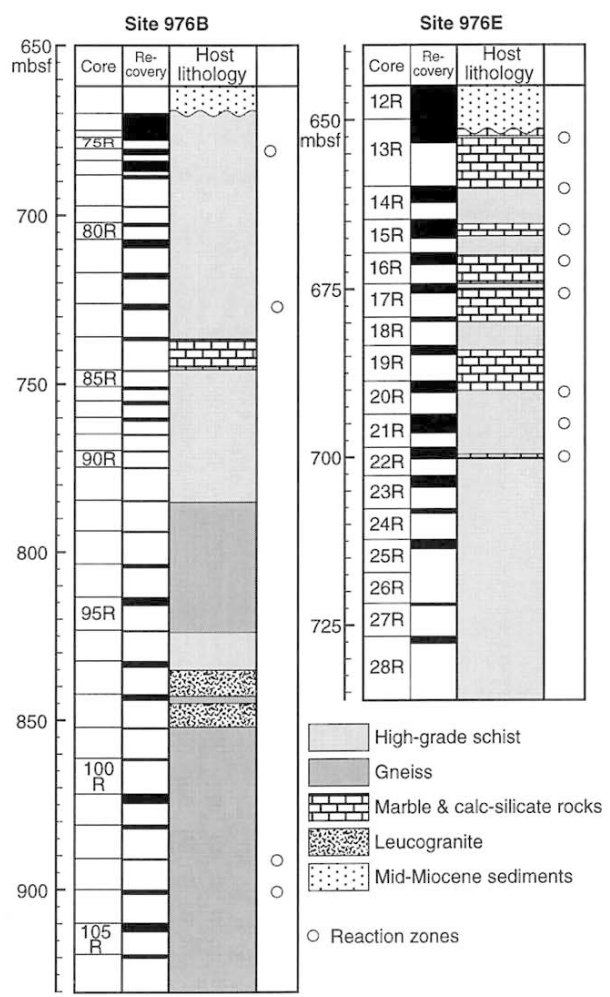

FIG. 1. (a) Location of Ocean Drilling Program (ODP) site 976 in the West Alborán Sea basin, with a schematic geological map of the surrounding Betic and Rif mountain chains (after Soto \& Platt 1999). The metamorphic basement high (shaded) near site 976 (from Comas et al. 1992) is similar to the exposed metamorphic complexes of the Alborán Domain. Bathymetry contour interval is $200 \mathrm{~m}$. AI: Alborán Island. (b) Schematic sequences of the metamorphic basement cored in ODP Hole 976B and Hole 976E (after Shipboard Scientific Party, 1996) show the location of the reaction zones. Recovered intervals are shown in black in the recovery column.

tonite), and natural sphalerite. Data were reduced using the PAP procedure from Pouchou \& Pichoir (1985). Representative compositions, mineral formulae and end-member proportions are shown in Table 1.

Major-element determinations in whole rocks were established by X-ray fluorescence (Philips 1404) after fusion with lithium tetraborate. Precision was typically better than $\pm 1.5 \%$ for a concentration of $10 \mathrm{wt} . \%$. Selected results of XRF analyses of several rock types involved in the reaction zones are shown in Table 2.

\section{DESCRIPTION OF THE REACTION ZONES}

Calc-silicate assemblages appear as green reaction zones, usually only up to a few centimeters thick, along the contact between calcite marbles and metapelites. Most commonly, they consist of prismatic or rounded porphyroblasts of clinopyroxene oriented parallel to the contact between the two rocks. In addition, the reaction zones may contain transposed fragments of pelites, and in many cases define isoclinal folds formed during a second event of deformation, $\mathrm{D}_{2}$ (Shipboard Scientific Party 1996).

The most complete sequence of mineral zones is observed, nevertheless, at the contact between corundum-bearing metapelites and calcite marbles. In this position, reaction zones occur as narrow bands up to $15 \mathrm{~mm}$ wide (Figs. 2a, 3). Six reaction zones with different assemblages can be distinguished according to significant textural and mineral changes, i.e., the appearance or disappearance of one or more phases. The boundaries between the zones are usually sharp.

The quartz-bearing metapelites interlayered with the corundum-bearing metapelites are also modified where they occur close to the reaction zones with the marble, giving rise to an individual zone (Zone III; see below). This commonly takes place near the hinge of isoclinal $\mathrm{D}_{2}$ folds (Fig. 2a). 
TABLE 1. REPRESENTATIVE COMPOSITIONS OF MINERALS IN REACTION ZONES FROM THE ALBORAN SEA BASEMENT, ODP LEG 161, SITE 976

\begin{tabular}{|c|c|c|c|c|c|c|c|c|c|c|c|c|c|c|c|}
\hline $\begin{array}{l}\text { Mineral } \\
\text { React. Zone } \\
\text { Point } \\
\text { Texture }\end{array}$ & $\begin{array}{r}\mathrm{Hc} \\
\text { II } \\
3-17\end{array}$ & $\begin{array}{c}\text { Mrg } \\
\text { pel. } \\
1-14 \\
\text { Crn } \\
\text { corona }\end{array}$ & $\begin{array}{c}\text { Bt } \\
\mathrm{J} \\
2-12 \\
\text { rim } \\
\mathrm{Hc}+ \\
\mathrm{Crn}\end{array}$ & $\begin{array}{l}\mathrm{Bt} \\
\text { III } \\
5-8 \\
\text { rim } \\
\mathrm{Grt} \\
4-8\end{array}$ & $\begin{array}{c}\text { Bt } \\
\text { III } \\
5-10 \\
\text { incl. } \\
\text { in Grt } \\
25-10\end{array}$ & $\begin{array}{c}\text { Bt } \\
\text { IV } \\
2-9 \\
\text { rim } \\
\text { Amp }\end{array}$ & $\begin{array}{c}\mathrm{Bt} \\
\text { marble } \\
1-19\end{array}$ & $\underset{3-10}{\mathrm{GIt}}$ & $\begin{array}{c}\text { Grt } \\
\text { IV } \\
1-4 \\
\text { near } \\
\text { Amp }\end{array}$ & $\begin{array}{r}\text { Grt } \\
\text { VI } \\
3-2\end{array}$ & $\begin{array}{c}\text { Hbl } \\
\text { IV } \\
3-4 \\
\text { rim } \\
\text { of } \\
\text { Grt 2-4 }\end{array}$ & $\begin{array}{l}\text { Prg } \\
\text { marble } \\
2-19 \\
4\end{array}$ & $\begin{array}{c}\text { Cpx } \\
V \\
1-18 \\
\text { near } \\
P 1\end{array}$ & $\begin{array}{r}\text { Cpx } \\
\text { VI } \\
6-3\end{array}$ & $\begin{array}{cc}\text { Cpx } & \text { Crn } \\
\text { marble pel. } & \text { per } \\
1-19 & 7-13 \\
\text { near } & \\
\text { Pl } & \end{array}$ \\
\hline
\end{tabular}

\begin{tabular}{|c|c|c|c|c|c|c|c|c|c|c|c|c|c|c|c|c|}
\hline $\mathrm{SiO}_{2} \mathrm{wt} \%$ & 0.00 & 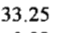 & 33.00 & .40 & 35.24 & 35.61 & 34.12 & 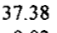 & 38.06 & . & 10 & . & & & & 0.00 \\
\hline $\mathrm{TiO}_{2}$ & 0.09 & 0.02 & 2.31 & 3.04 & 2.55 & 3.23 & 2.41 & 0.03 & 0.05 & 0.14 & 1.00 & 1.04 & 0.11 & 0.13 & 0.17 & 0.00 \\
\hline $\mathrm{Cr}_{2} \mathrm{O}_{3}$ & 0.12 & 0.00 & 0.01 & 0.00 & 0.04 & 0.03 & 0.02 & 0.06 & 0.08 & 0.02 & 0.02 & 0.07 & 0.05 & 0.03 & 0.06 & 0.01 \\
\hline $\mathrm{Al}_{2} \mathrm{O}_{3}$ & 56.16 & 48.83 & 19.85 & 14.97 & 14.99 & 15.39 & 16.33 & 20.93 & 20.96 & 19.81 & 11.02 & 15.34 & 0.92 & 0.96 & 1.25 & 99.56 \\
\hline $\mathrm{Fe}_{2} \mathrm{O}_{3}$ & 3.17 & 0.00 & 0.00 & 4.30 & 4.05 & 4.38 & 2.75 & 0.24 & 0.15 & 2.23 & 0.46 & 2.20 & 0.97 & 0.00 & 0.00 & 0,00 \\
\hline $\mathrm{FeO}^{(1)}$ & 37.37 & 0.12 & 25.57 & 21.26 & 22.18 & 20.49 & 23.15 & 29.63 & 25,90 & 11.54 & 21.67 & 20.84 & 13.77 & 18.49 & 14.53 & 0.25 \\
\hline $\mathrm{MnO}$ & 0.52 & 0.00 & 0.20 & 0.28 & 0.22 & 0.17 & 0.12 & 3.25 & 4.07 & 2.96 & 0.44 & 0.22 & 0.49 & 0.56 & 0.47 & 0.01 \\
\hline $\mathrm{MgO}$ & 1.87 & 0.01 & 4.54 & 7.54 & 7.49 & 7.95 & 7.08 & 1.65 & 1.43 & 0.23 & 6.48 & 4.65 & 8.92 & 6.23 & 8.67 & 0.00 \\
\hline $\mathrm{ZnO}$ & 0.57 & b.d. & b.d. & b.d. & b.d. & b.d. & b.d. & b.d. & b.d. & b.d. & b.d. & b.d. & b.d. & b.d. & b.d. & b.d. \\
\hline $\mathrm{NiO}$ & 0.00 & 0.00 & b.d. & b.d. & b.d. & b.d. & b.d. & b.d. & b.d. & b.d. & b.d. & b.d. & b.d. & b.d. & d. & 0.00 \\
\hline $\mathrm{CaO}$ & 0.00 & 10.57 & 0.03 & 0.05 & 0.08 & 0.04 & 0.12 & 6.85 & 10.08 & 24.58 & 11.52 & 11.83 & 23. & 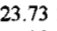 & 40 & 0.00 \\
\hline $\mathrm{Na}_{2} \mathrm{O}$ & 0.00 & 1.01 & 0.13 & 0.08 & 0.07 & 0.05 & 0.08 & 0.01 & 0.00 & 0.00 & 0.81 & 0.21 & 0.02 & 0.00 & 0.01 & 0.00 \\
\hline $\mathrm{K}_{2} \mathrm{O}$ & 0.00 & 0.96 & 8.89 & 8.60 & 8.62 & 8.80 & 9.27 & 0.00 & 0.02 & 0.00 & 1.05 & 4.13 & 0.00 & 0.00 & 0.01 & 0.00 \\
\hline F & b.d. & 0.00 & b.d. & b.d. & b.d. & b.d. & b.d. & b.d. & b.d. & b.d. & b.d. & b.d. & b.d. & b.d. & b.d. & b.d. \\
\hline $\mathrm{Cl}$ & d. & 0.00 & 0.05 & 0.09 & 0.09 & 0.09 & b.d. & b.d. & b.d. & b.d. & b.d. & b.d. & b.d. & b.d. & b.d. & b.d. \\
\hline $\mathrm{H}_{2} \mathrm{O}^{(2)}$ & b.d. & 4.52 & 3,76 & 3.84 & 3.82 & 3.88 & 3.82 & b.d. & b.d. & b.d. & 1.96 & 1.90 & b.d. & b.d. & b.d. & b.d. \\
\hline Total $^{1}$ & 99.29 & 94.77 & 94.58 & 95.69 & 95.62 & 96.23 & 95.4 & 100.041 & 100.00 & .26 & .85 & 97.63 & $99.44 \mathrm{l}$ & 70 & 9.53 & .84 \\
\hline Si apfu & 0.00 & 2.21 & 2.62 & 2.75 & 2.75 & 74 & & 3.0 & 1 & 3.02 & 6.64 & 5.86 & 1. & 1.97 & 1.98 & 0.00 \\
\hline Ti & 0.00 & 0.00 & 0.14 & 0.18 & 0.15 & 0.19 & 0.14 & 0.00 & 0.00 & 0.00 & 0.12 & 0.12 & 0.00 & 0.00 & 0.00 & 0.00 \\
\hline $\mathrm{Cr}$ & 0.00 & 0.00 & 0.00 & 0.00 & 0.00 & 0.00 & 0.00 & 0.00 & 0.00 & 0.00 & 0.00 & 0.00 & 0.00 & 0.00 & 0.00 & 0.00 \\
\hline Al total & 1.92 & 1.80 & 1.38 & 1.25 & 1.25 & 1.26 & 1.32 & 0.00 & 0.00 & 0.00 & 1.36 & 2.14 & 0.04 & 0.03 & 0.02 & 2.00 \\
\hline${ }^{\mathrm{V}} \mathrm{Al}$ & b.d. & 2.02 & 0.48 & 0.12 & 0.13 & 0.13 & 0.19 & 1.98 & 1.96 & 1.82 & 0.63 & 0.72 & 0.00 & 0.02 & 0.03 & b.d. \\
\hline $\mathrm{Fe}^{3+}$ & 0.07 & 0.00 & 0.00 & 0.25 & 0.24 & 0.25 & 0.16 & 0.01 & 0.00 & 0.13 & 0.05 & 0.26 & 0.03 & 0.00 & 0.00 & 0.00 \\
\hline $\mathrm{Fe}^{2 \prime}$ & 0.91 & 0.00 & 1.70 & 1.38 & 1.45 & 1.32 & 1.52 & 1.99 & 1.71 & 0.75 & 2.77 & 2.76 & 0.45 & 0.60 & 0.47 & 0.00 \\
\hline $\mathrm{Mn}$ & 0.01 & 0.00 & 0.01 & 0.02 & 0.01 & 0.01 & 0.00 & 0.22 & 0.27 & 0.20 & 0.06 & 0.03 & 0.02 & 0.02 & 0.02 & 0.00 \\
\hline $\mathrm{Mg}$ & 0.08 & 0.00 & 0.54 & 0.87 & 0.87 & 0.91 & 0.83 & 0.20 & 0.17 & 0.03 & 1.48 & 1.10 & 0.52 & 0.36 & 0.50 & 0.00 \\
\hline $\mathrm{Zn}$ & 0.01 & b.d. & b.d. & b.d. & b.d. & b.d. & b.d. & b.d. & b.d. & b.d. & b.d. & b.d. & b.d. & b.d. & b.d. & 0.00 \\
\hline $\mathrm{Ni}$ & 0.00 & 0.00 & b.d. & b.d. & b.d. & b.d. & b.d. & b.d. & b.d. & b.d. & b.d. & b.d. & b.d. & b.d. & b.d. & 0.00 \\
\hline $\mathrm{Ca}$ & 0.00 & 0.75 & 0.00 & 0.00 & 0.00 & 0.00 & 0.01 & 0.59 & 0.86 & 2.05 & 1.89 & 2.00 & 0.98 & 0.99 & 0.97 & 0.00 \\
\hline Na total** & 0.00 & 0.13 & 0.02 & 0.01 & 0.01 & 0.00 & 0.01 & 0.00 & 0.00 & 0.00 & 0.24 & 0.06 & 0.00 & 0.00 & 0.00 & 0.00 \\
\hline $\mathbf{K}$ & 0.00 & 0.08 & 0.90 & 0.85 & 0.86 & 0.86 & 0.93 & 0.00 & 0.00 & 0.00 & 0.20 & 0.83 & 0.00 & 0.00 & 0.00 & 0.00 \\
\hline $\mathbf{F}$ & b.d. & 0.00 & b.d. & b.d. & b.d. & b.d. & b.d. & b.d. & b.d. & b.d. & b.d. & b.d. & b.d. & b.d. & b.d. & b.d. \\
\hline $\mathrm{Cl}$ & b.d. & 0.00 & 0.00 & 0.01 & 0.01 & 0.01 & b.d. & b.d. & b.d. & b.d. & b.d. & b.d. & b.d. & b.d. & b.d. & b.d. \\
\hline $\mathrm{OH}^{-}$ & b.d. & 2.00 & 1.99 & 1.99 & 1.99 & 1.99 & 2.00 & b.d. & b.d. & b.d. & 2.00 & 2.00 & b.d. & b.d. & b.d. & b.d. \\
\hline
\end{tabular}

Calculation schemes: hercynite: 3 cations and $4 \mathrm{O}$; biotite: cations $-\mathrm{Na}-\mathrm{K}=7-\mathrm{Ti}$ and 110 ; gamet: 8 cations and $12 \mathrm{O}$; amphiboles: 15 cations - $\mathrm{Na}-\mathrm{K}$; clinopyroxene: 4 cations and $6 \mathrm{O}$ (following Wood \& Banno 1973); corundum: $3 \mathrm{O}$. (1) Proportions of $\mathrm{FeO}$ and $\mathrm{Fe}_{2} \mathrm{O}_{3}$ were calculated from stoichiometry for $\mathrm{Hc}, \mathrm{Mrg}$, Bt, Grt, Amp, and $\mathrm{Cpx}$. ${ }^{(2)} \mathrm{H}_{2} \mathrm{O}$ back-calculated from stoichiometry for $\mathrm{Mrg}, \mathrm{Bt}$, and amphibole. Incl. : inclusion, Pel.: metapelite. $\mathrm{Hbl}$ : ferrohomblende, Prg: ferropargasite, Amp: amphibole. Otherwise, mineral abbreviations after Kretz (1983). All analyses were done on sample 161-976B-76R-1, Piece 9a, 75-79 cm. ${ }^{1}$ Total [ $\left.-\mathrm{H}_{2} \mathrm{O}\right]$. b.d.: below detection. ${ }^{*} \mathrm{Or}^{\mathrm{IV}} \mathrm{Al}$. ${ }^{*}{ }^{*} \mathrm{Or}^{\mathrm{N4}}{ }^{\mathrm{Na}}$

Compositional parameters and end members: $\mathrm{Hc} 3-17: \mathrm{Hc}_{0.87} \mathrm{Spl}_{0.08} \mathrm{Mgt}_{0.03} . \mathrm{Mrg} 1-14: X_{\mathrm{Mg}}=\mathrm{Mg} /\left(\mathrm{Mg}+\mathrm{Fe}^{2+}\right)=0.19$ Bt 2-12: $X_{\mathrm{Mq}}=0.24$, Bt 5-8: $X_{\mathrm{Mg}_{8}}=0.39$, Bt 5-10: $X_{\mathrm{Mg}}=0.38$, Bt 2-9: $X_{\mathrm{Mg}_{8}}=0.41$, Bt 1-19: $X_{\mathrm{Mg}_{8}}=0.35$. Grt 3-10: $X_{\mathrm{Mg}}=0.09, X_{\mathrm{Gr}}=0.19, X_{\mathrm{Amm}}=0.66, X_{\mathrm{Prp}}=0.07, X_{\mathrm{Spa}}=0.07, X_{\mathrm{Adr}}=0.01$. Grt 1-4: $X_{\mathrm{Mg}}=0.09, X_{\mathrm{Gr}}=0.28, X_{\mathrm{Altr}}=0.57$, $X_{\mathrm{Ptp}}=0.06, X_{\mathrm{Spt}}=0.09, X_{\mathrm{Adr}}=0.00$. Git 3-2: $X_{\mathrm{Mg}}=0.04, X_{\mathrm{Gr}}=0.61, X_{\mathrm{Alm}}=0.25, X_{\mathrm{PTp}}=0.01, X_{\mathrm{spe}}=0.07, X_{\mathrm{Adr}}=$ 0.07 . Ferrohornblende 3-4: $X_{\mathrm{Mg}}=0.35, X_{\mathrm{Ts}}=0.92, X_{\mathrm{Ed}}=0.45,{ }^{A}(\mathrm{~K}+\mathrm{Na})=0.46$. Ferropargasite 2-19: $X_{\mathrm{Mg}}=0.29, X_{\mathrm{T}}$

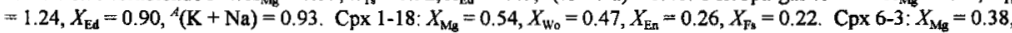
$X_{\mathrm{Wo}}=0.49, X_{\mathrm{En}}=0.18, X_{\mathrm{Fs}}=0.30 . \mathrm{Cpx} 1-19: X_{\mathrm{Mg}}=0.52, X_{\mathrm{Wo}}=0.48, X_{\mathrm{En}}=0.25, X_{\mathrm{Fu}}=0.24$.

\section{Corundum-bearing metapelite}

This rock consists of corundum + biotite + plagioclase + K-feldspar + ilmenite \pm garnet \pm sillimanite \pm andalusite, together with retrograde muscovite and margarite. Corundum appears as isolated small rounded grains in a biotite-rich matrix or as larger skeletal poikiloblasts (up to $25 \mu \mathrm{m}$ ). The main foliation $\left(S_{2}\right)$ is defined by biotite, plagioclase, and scarce ilmenite (Figs. 2b, 3). Garnet occurs as large porphyroblasts usually with inclusion trails of ilmenite and graphite de- fining an internal foliation, oblique to the external $\mathrm{S}_{2}$ foliation. Garnet porphyroblasts are zoned, with increasing contents of almandine and pyrope and a decreasing proportion of grossular and spessartine from core to rim $\left(\mathrm{Alm}_{48-65} \mathrm{Grs}_{35-20} \mathrm{Sps}_{15-12} \mathrm{Prp}_{5-8}\right.$; Fig. 4) (Soto \& Platt 1999). Sillimanite occurs as elongate mats of fibrous crystals defining the $\mathrm{S}_{2}$ foliation. Andalusite forms large poikiloblastic porphyroblasts randomly oriented, growing over $\mathrm{S}_{2}$, and are partially transformed to muscovite. The modal abundance of both Al-silicates and garnet tends to diminish toward the reaction zone, 

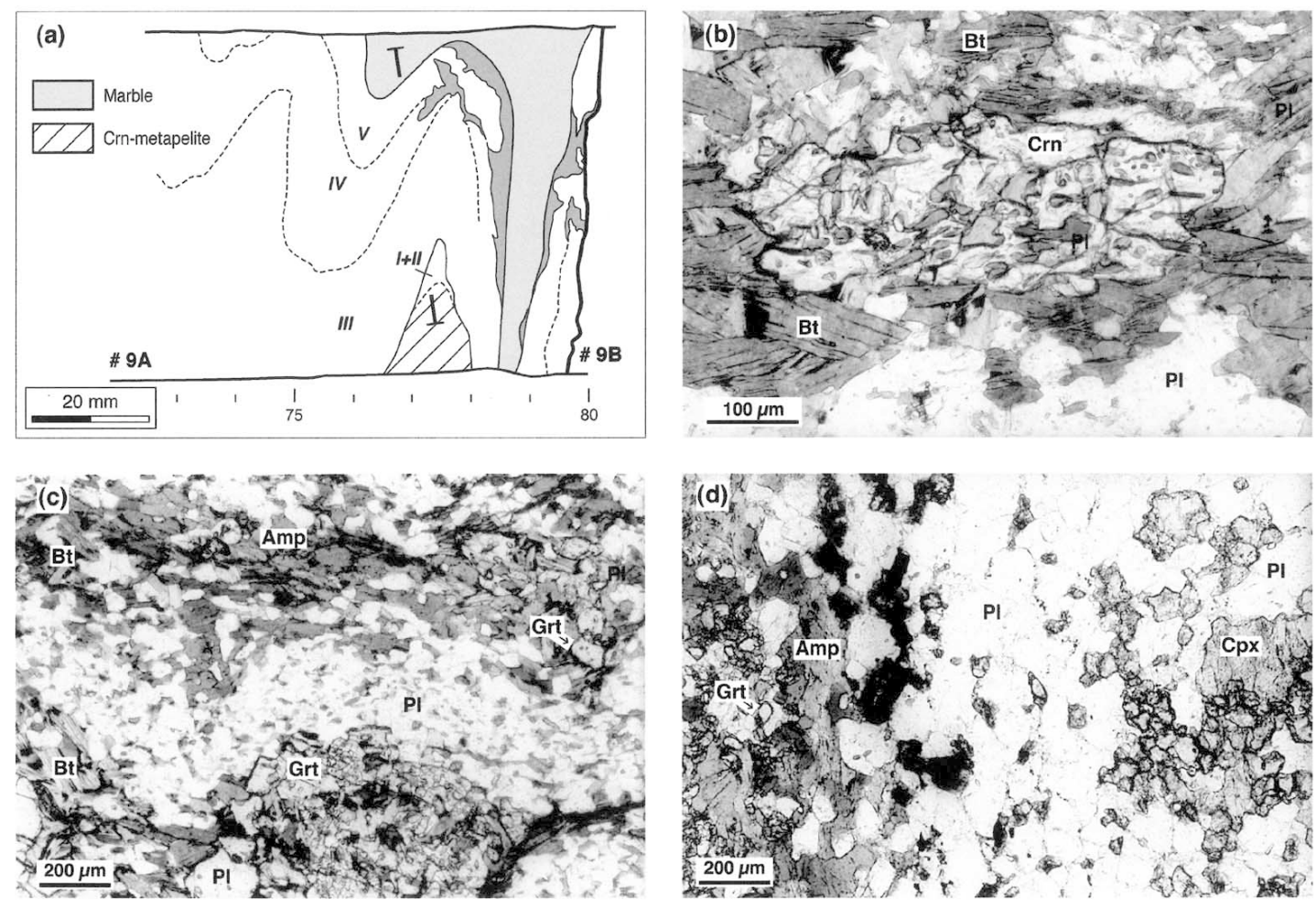

FIG. 2. a. Sketch showing the occurrence of reaction zones in the contact between the calcite marble and metapelite (sketch drawn from a photograph of the core). The alteration zone, in dark shading, occurs partially superposed onto zones IV to VI, and along the contact with the marble. Approximate limits between reaction zones are shown on the basis of thin-section obervations and core description. Bold lines mark the location of the modeled profile across the reaction zones (sample 976B76R1, pieces 9a and 9b). b. Photomicrograph, plane-polarized light, of corundum in the metapelite. c. Photomicrograph, plane-polarized light, of the contact between zone III (below; with garnet, biotite, and plagioclase) and zone IV (above; with amphibole, biotite, garnet, and plagioclase). The contact between the two zones is marked by the appearance of amphibole in zone IV. d. Photomicrograph, plane-polarized light, of the contact between zone IV (left; with garnet, amphibole, and plagioclase) and zone V (right; with clinopyroxene, plagioclase, and quartz). Mineral abbreviations after Kretz (1983); Amp: amphibole, and Cpx: clinopyroxene.

and generally they even completely disappear (Fig. 3a). This can be interpreted as a metasomatism-induced feature of the rock.

\section{Zone I}

This zone is defined by the appearance of hercynite coexisting with corundum, and the absence of sillimanite, andalusite, and garnet. It is commonly observed at the core of $\mathrm{D}_{2}$ isoclinal folds (Fig. 2a). In this zone, the hercynite grains increase in size away from the boundary with the corundum-bearing metapelite, concomitantly with a decrease in the modal abundance of corundum (Fig. 3b). The other minerals present in this zone are plagioclase + biotite $+\mathrm{K}$-feldspar + ilmenite + margarite. Hercynite $\left(\mathrm{Hc}_{95-94},<0.6 \mathrm{wt} \%\right.$ $\mathrm{ZnO}$ ) is found as dark green skeletal porphyroblasts of variable size (up to $25 \mu \mathrm{m}$ ) with a preferred orientation parallel to $\mathrm{S}_{2}$, or as smaller grains dispersed in the matrix with biotite and plagioclase ( $\left.\mathrm{An}_{98-92}\right)$ porphyroblasts. Skeletal porphyroblasts of hercynite are invariably intergrown with biotite, plagioclase, and abundant blades of ilmenite, and commonly together with aggregates of corundum (Fig. 3b).

\section{Zone II}

This zone is defined by the disappearance of corundum and the progressive decrease in modal abundance and size of the hercynite grains $\left(\mathrm{Hc}_{93-91}\right)$ toward the boundary with Zone III (Fig. 3b). The composition of biotite varies from the corundum-bearing metapelite to Zones I and II, and it is clearly determined by the composition of the associated minerals (Fig. 5). For 
TABLE 2. RESULTS OF SELECTED XRF ANALYSES OF

CORUNDUM-BEARING METAPELITE, MARBLE AND A GT + Pl + CpX REACTION ZONE

FROM THE ALBORÁN SEA BASEMENT, ODP LEG 161, SITE 976

\begin{tabular}{|c|c|c|c|}
\hline $\begin{array}{l}\text { Rock } \\
\text { type } \\
\text { Sample }\end{array}$ & $\begin{array}{c}\text { Crn-bearing } \\
\text { schist } \\
161-976 \mathrm{~B}-77 \mathrm{R} 2 \\
40-44 \mathrm{~cm}(\# 31)\end{array}$ & $\begin{array}{c}\text { Impure calcite } \\
\text { marble } \\
161-976 \mathrm{E}-17 \mathrm{R} 2 \\
31-35 \mathrm{~cm}(\# 21)\end{array}$ & $\begin{array}{c}\mathrm{Grt}+\mathrm{PI}+\mathrm{CPx}_{\mathrm{Px}} \\
\text { reaction zone } \\
161-976 \mathrm{~B}-76 \mathrm{R} 2 \\
111-114 \mathrm{~cm}(\# 35)\end{array}$ \\
\hline $\mathrm{SiO}_{2} \mathrm{wt} \%$ & 57.04 & 22.87 & 44.63 \\
\hline $\mathrm{TiO}_{2}$ & 0.80 & 0.35 & 0.61 \\
\hline $\mathrm{Al}_{2} \mathrm{O}_{3}$ & 16.71 & 7.14 & 14.53 \\
\hline $\mathrm{Fe}_{2} \mathrm{O}_{3}$ & 11.43 & 2.69 & 11.64 \\
\hline $\mathrm{MnO}$ & 0.20 & 0.06 & 0.23 \\
\hline $\mathrm{MgO}$ & 3.70 & 0.86 & 3.61 \\
\hline $\mathrm{CaO}$ & 2.67 & 34.83 & 21.12 \\
\hline $\mathrm{Na}_{2} \mathrm{O}$ & 0.43 & 0.48 & 0.22 \\
\hline $\mathrm{K}_{2} \mathrm{O}$ & 3.90 & 1.57 & 0.31 \\
\hline $\mathrm{P}_{2} \mathrm{O}_{5}$ & 0.17 & 0.09 & 0.18 \\
\hline Total & 97.05 & 70.94 & 97.08 \\
\hline $\mathrm{LOI}^{(2)}$ & 2.96 & 28.23 & 2.23 \\
\hline A & 58.40 & 9.87 & 31.33 \\
\hline C & 13.14 & 86.99 & $\$ 4.97$ \\
\hline F & 28.47 & 3.13 & 13.70 \\
\hline
\end{tabular}

(1) All iron as $\mathrm{Fe}_{2} \mathrm{O}_{3}$. (2) LOI: loss on ignition at $1000^{\circ} \mathrm{C}$.

example, biotite in contact with corundum (metapelite and Zone I) is richer in ${ }^{\mathrm{VI}} \mathrm{Al}$ and $\mathrm{Ti}$, whereas biotite in contact with hercynite and ilmenite (Zone II) has higher $X_{\mathrm{Mg}}$ values. Biotite in all the zones corresponds, nevertheless, to annite (i.e., $X_{\mathrm{Mg}}<0.5$ and ${ }^{\mathrm{VI}} \mathrm{Al}<0.5$; Rieder et al. 1998). Margarite $\left(\operatorname{Mrg}_{82-61}\right)$ occurs as very thin $(<10 \mu \mathrm{m})$ radial, low-birrefringence aggregates of secondary origin surrounding both corundum and hercynite in Zones I and II and in the metapelite.

\section{Zone III}

Zone III contains biotite + garnet + plagioclase $+\mathrm{K}$ feldspar. This zone grades away from the reaction band to the common quartz-bearing metapelite interlayered with the corundum-bearing assemblages. Biotite and hypidiomorphic to xenomorphic porphyroblasts of garnet (up to $30 \mu \mathrm{m}$ across) define the main foliation $\left(S_{2}\right)$ in Zone III. The biotite in this zone is richer in $\mathrm{Mg}$ and poorer in Al (Fig. 5) than biotite in Zones I and II, whereas its Ti content is similar. The garnet is crowded with inclusions of biotite and plagioclase parallel and

FIG. 3. Textural variations from the corundum-bearing metapelite to calcite marble. Bold dashed line indicates the location of the reaction-zone boundaries. Note that the complete thickness of the reaction zones I, II, V, and VI is not shown and that the sketch (c) has a slightly smaller scale. Sketch drawn after photomicrographs (sample 976B-76R-1, piece 9a, 75-79 cm).

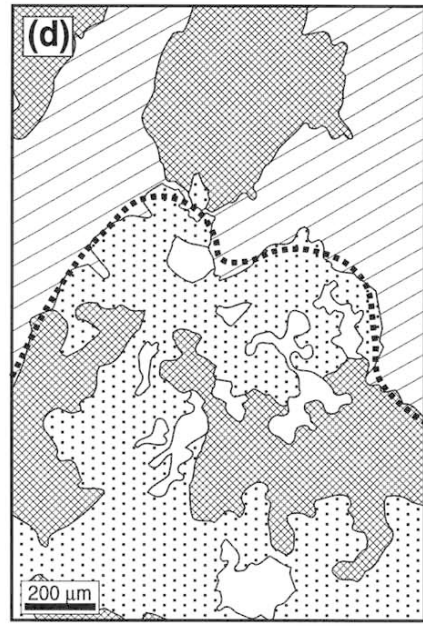

Marble

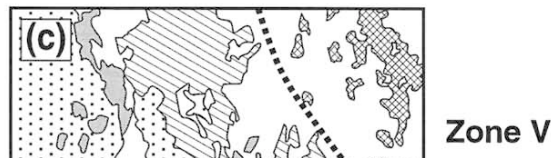

Zone VI

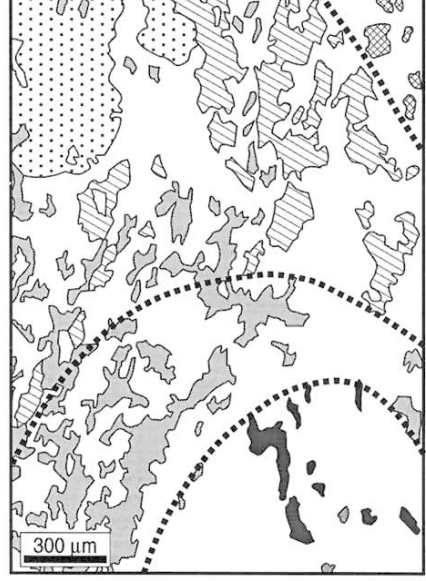

Zone IV

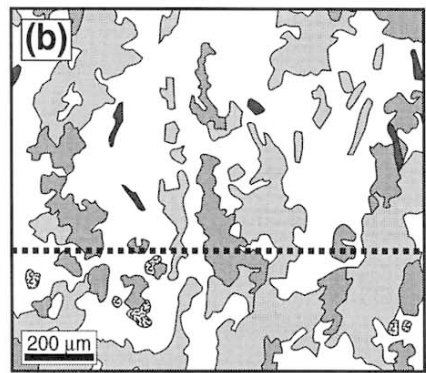

Zone II

Zone II

\section{Zone I}

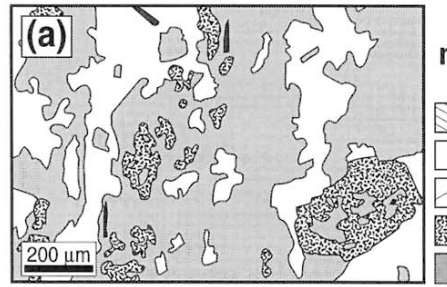

Crnmetapelite

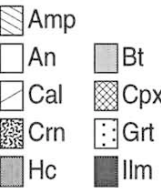




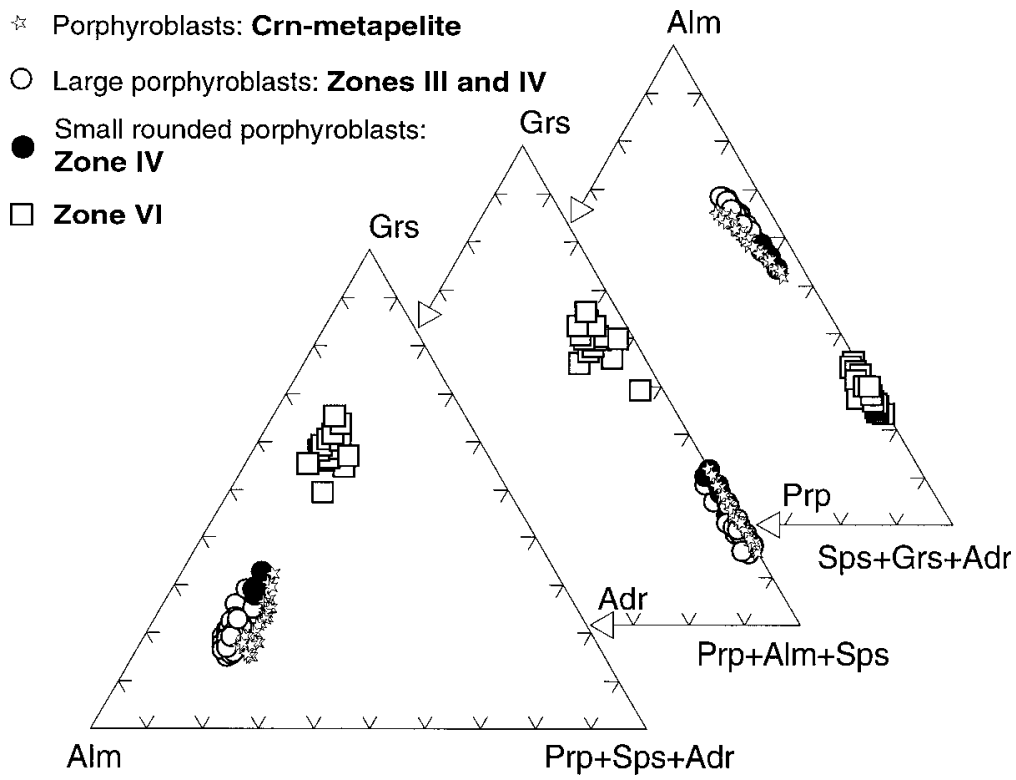

FIG. 4. Garnet compositions in the reaction zones in terms of almandine (Alm), pyrope (Prp), grossular (Grs), spessartine (Sps), and andradite (Adr) components (mineral abbreviations after Kretz 1983). Stars represent garnet porphyroblasts in corundum-bearing metapelites away from the reaction zones (data taken from Soto \& Platt 1999). Open circles represent garnet porphyroblasts in contact with biotite in zones III and IV, solid circles represent small rounded porphyroblasts in contact with amphibole in zone $\mathrm{IV}$, triangles represent small relics of garnet in the alteration zone, and squares represent garnet in contact with clinopyroxene in zone VI.

continuous with the external foliation (Fig. 2c), and is in some cases altered to chlorite. Garnet is essentially an almandine - grossular solid solution with low contents of pyrope $(<10 \%)$ and spessartine (Fig. 4). The garnet shows a fairly constant composition and flat patterns of zoning. Plagioclase appears as small rounded grains in the matrix, and it is almost pure anorthite $\left(\mathrm{An}_{95-97}\right)$.

\section{Zone IV}

Zone IV consists of amphibole + biotite + garnet + plagioclase $+\mathrm{K}$-feldspar. This zone is defined by the appearance of tabular aggregates of green-brown amphibole coexisting with biotite, plagioclase, and large porphyroblasts of garnet near the contact with Zone III (Fig. 3c). Toward the central part of the zone, biotite tends to disappear, and garnet occurs as aggregates of small rounded grains in contact with amphibole and plagioclase (Fig. 2c). Amphibole has not been reported previously in metapelites from the Alborán Basement (Soto et al. 1999), and its appearance here is attributed to the interaction between the marble and the metapelite. The amphibole is a ferrohornblende (Leake et al. 1997) and can basically be defined as a solid solution between tremolite $\left(X_{\operatorname{Tr}}\right.$ in the range $\left.0.12-0.4\right)$, pargasite $\left(X_{\operatorname{Prg}}\right.$ in the range $0.38-0.58)$, and tschermakite $\left(X_{\mathrm{Ts}}\right.$ in the range $0.16-0.36$ ), with $0.31<X_{\mathrm{Mg}}<0.37$ and a significant $\mathrm{K}$ for-Na substitution in $A$ site ( $X_{\mathrm{K}}$ in the range $\left.0.45-0.57\right)$. The composition of biotite is very similar to that from Zone III, except for a slightly higher $X_{\mathrm{Mg}}$ value (Fig. 5). Small rounded grains of garnet are richer in grossular $\left(\mathrm{Grs}_{25-33}\right)$ and poorer in almandine $\left(\mathrm{Alm}_{54-59}\right)$ and pyrope $\left(\operatorname{Prp}_{5-6}\right)$ than those forming large porphyroblasts (Fig. 4). The plagioclase is $\mathrm{An}_{96-99}$.

\section{Zone V}

This zone has a sharp contact with Zone IV (Figs. $2 \mathrm{~d}, 3 \mathrm{c})$ and is formed by a granoblastic aggregate of plagioclase, clinopyroxene, titanite, and scarce pyrite. Plagioclase $\left(\mathrm{An}_{99}\right)$ and clinopyroxene $\left(\mathrm{Hd}_{47}\right)$ have a very homogeneous composition.

\section{Zone VI}

Zone VI contains clinopyroxene + garnet + plagioclase + calcite + titanite + pyrite. This zone is discontinuous along the length of the reaction band; where it is absent, the contact between Zone $\mathrm{V}$ and the marble is sharp and defined by the appearance of larger porphyro- 

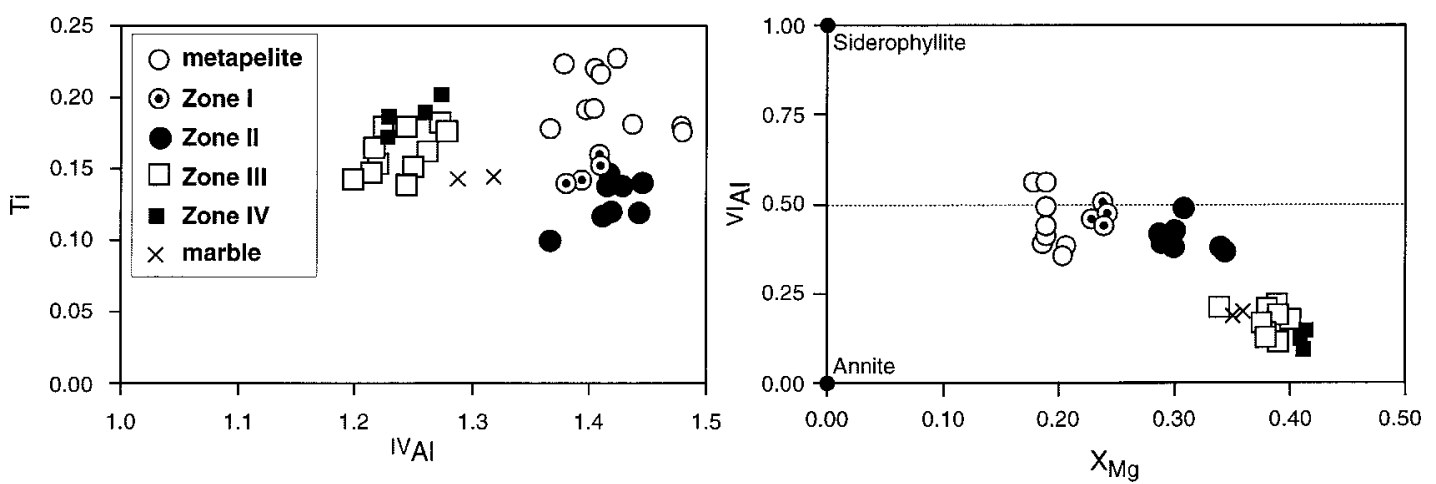

FIG. 5. Plot of ${ }^{\mathrm{IV}} \mathrm{Al}$ versus $\mathrm{Ti}$, and $X_{\mathrm{Mg}}$ versus ${ }^{\mathrm{VI}} \mathrm{Al}$ variation in biotite.

blasts of clinopyroxene (Fig. 3d). Zone VI consists of an intergrowth of xenomorphic grains of clinopyroxene and garnet, occasionally together with large crystals of subidiomorphic titanite and xenomorphic pyrite. The garnet is partially retrograded to plagioclase, calcite, and quartz, and clinopyroxene, to actinolitic amphibole. The garnet in Zone VI has higher grossular (Grs49-65) and andradite $\left(\mathrm{Adr}_{3-9}\right)$ contents and much lower almandine $\left(\mathrm{Alm}_{23-34}\right)$ and pyrope $\left(\operatorname{Prp}_{0.6-2}\right)$ values than garnet in other zones (Fig. 4). The clinopyroxene varies widely in its $X_{\mathrm{Mg}}$ ratio $\left(\mathrm{Hd}_{44-67}\right)$, whereas plagioclase is again very close to the anorthite end-member ( $\left.\mathrm{An}_{94-99}\right)$.

\section{Marble}

The marble is an impure calcite marble with small dispersed grains of clinopyroxene, amphibole, biotite, and plagioclase. The amphibole is a ferroan pargasite (Leake et al. 1997) with $X_{\operatorname{Prg}}$ in the range 0.88-0.90, $X_{\mathrm{Ts}}$ in the range $0.1-0.2, X_{\mathrm{Mg}}$ in the range $0.29-0.31$ and $X_{\mathrm{K}}$ in the range $0.88-0.93$. Biotite is compositionally very similar to those from Zones III and IV (Fig. 5). Clinopyroxene and plagioclase have homogeneous compositions near $\mathrm{Hd}_{50}$ and $\mathrm{An}_{99}$, respectively.

Alteration has partially affected Zones V and VI and the marble (Fig. 2a); a yellow to brownish aggregate of submicroscopic sheet silicates developed at the expense of clinopyroxene, partially transformed to actinolitic amphibole, together with andradite-rich garnet, titanite, large grains of anorthite-rich plagioclase, and calcite.

\section{P-T Conditions During the Formation OF THE REACTION ZONES}

Mass-transfer processes producing metamorphic reaction-zones are more easily modeled assuming constant $\mathrm{P}$ and T conditions (Thompson 1975, Brady 1977, Kerrick 1977, Glassley 1983, van Marcke de Lummen \& Verkaeren 1986, Joesten 1991). We have first esti- mated the P-T conditions for the mineral assemblage occurring in the contact between the corundum metapelite and Zone I. We assume, following Thompson (1959), that local equilibrium exists in the contact between two consecutive zones, characterized by a small number of phases and a high thermodynamic variance. This assumption allows one firstly to overcome the problem of the high thermodynamic variance of the assemblages of each single zone for purposes of making thermobarometric estimations, and, secondly, to elucidate the origin of corundum and hercynite in these rocks.

The existence of local equilibrium in the contact between the corundum metapelite and Zone I is in agreement with the reaction stoichiometries calculated by analysis of phase relations between the mineral assemblages of the two zones. Calculations were made using the program C-space of Torres Roldán et al. (2000), based on the algebraic technique of singular-value decomposition of Fisher $(1989,1993)$. Using the real chemical compositions of minerals from both zones, we obtained the following reaction:

$$
\begin{aligned}
& \text { 76.62 } \mathrm{Bt}+28160.07 \mathrm{Crn}+79.30 \mathrm{Pl}+66.98 \mathrm{Ilm} \\
& (\mathrm{Crn} \text { metapelite })= \\
& 54.25 \mathrm{Bt}+28195.36 \mathrm{Crn}+12.50 \mathrm{Hc}+77.37 \mathrm{Pl}+ \\
& 1.0 \mathrm{~K}_{2} \mathrm{O}(\text { Zone } \mathrm{I})
\end{aligned}
$$

which shows that the mineral assemblage found in Zone I can be derived directly from that of the corundum metapelite with a minor addition of $\mathrm{K}_{2} \mathrm{O}$.

Hence, we have calculated a $\mathrm{P}-\mathrm{T}$ projection for the mineral assemblage of the corundum-bearing metapelite and Zone I, consisting of biotite + plagioclase + K-feldspar + corundum + hercynite \pm garnet \pm sillimanite in the system $\mathrm{SiO}_{2}-\mathrm{Al}_{2} \mathrm{O}_{3}-\mathrm{CaO}-\mathrm{K}_{2} \mathrm{O}-\mathrm{FeO}-\mathrm{MgO}-\mathrm{H}_{2} \mathrm{O}$ (Fig. 6). The $\mathrm{Na}_{2} \mathrm{O}$ component was not considered, as it is only present in minor amounts in plagioclase. The calculations were made using the Vertex program of 


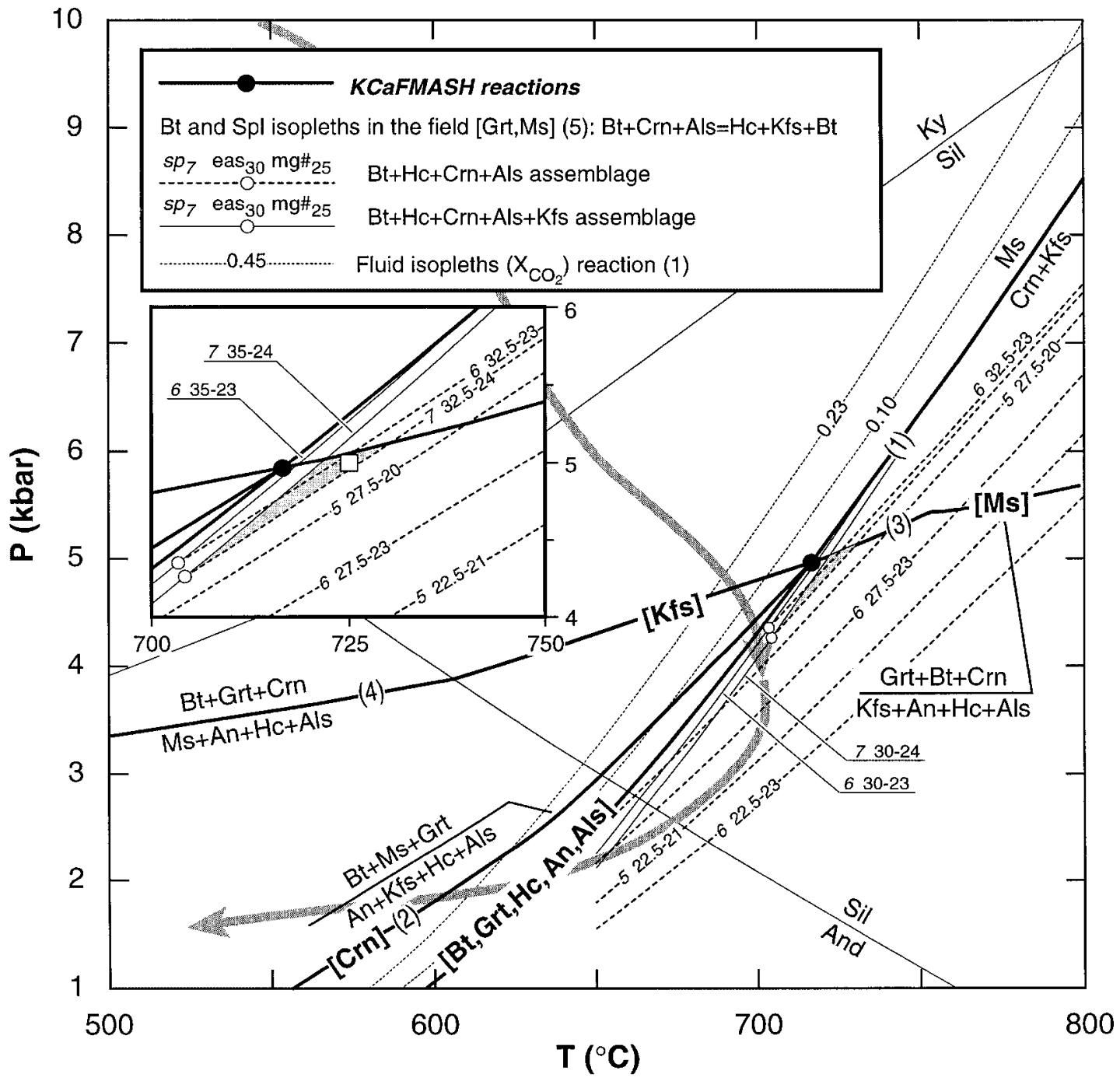

FIG. 6. P-T projection calculated for quartz-absent and corundum-bearing assemblages (metapelite and reaction Zone I) in the system $\mathrm{CaO}-\mathrm{K}_{2} \mathrm{O}-\mathrm{FeO}-\mathrm{MgO}-\mathrm{Al}_{2} \mathrm{O}_{3}-\mathrm{SiO}_{2}$, after projection through $\mathrm{H}_{2} \mathrm{O}$. Solid thick curves represent univariant equilibria. The solid black circle is an invariant point. Dashed and continuous thin lines are biotite and spinel isopleths corresponding to the high-variance reactions (5) and (6) (see text for details). Dotted lines show the displacement of the reaction [Bt, Grt, Hc, An, Als] (1) for variable composition of the fluid phase, expressed in terms of $X\left(\mathrm{CO}_{2}\right)$. Inset shows enlarged the relationships around the estimated P-T conditions for the formation of the reaction zones (shaded area). Note the close correspondence between the observed and the calculated mineral compositions ( $c f$. Table 3). P-T conditions selected for the chemical potential analysis (Fig. 8) are indicated in the inset with a white square $\left(725^{\circ} \mathrm{C}, 5 \mathrm{kbar}\right)$. The P-T path of the high-grade metapelites from the Alborán Sea basement is also shown for reference (taken from Soto \& Platt 1999). Numbers refer to reactions described in the text.

Connolly (1990), the thermodynamic database of Holland \& Powell (1990, modified in 1994), and the fluid equation of state of Holland \& Powell (1991).

The following minerals were considered pure phases in the calculations: Al-silicates, anorthite, corundum,
K-feldspar, and muscovite. Ideal solid-solution models have been used for biotite (phlogopite, annite, eastonite, and siderophyllite end-members) and hercynite (hercynite and spinel end-members), whereas for garnet we used the ternary solid-solution model of Berman 
TABLE 3. OBSERVED AND PREDICTED COMPOSITIONS OF SAMPLE 161-976B-76R-1, 75-79 cm

FROM THE ALBORAN SEA BASEMENT, ODP LEG 161, SITE 976

\begin{tabular}{|c|c|c|}
\hline Mineral & Observed composition & Predicted composition \\
\hline \multicolumn{3}{|c|}{ Zone I - Crn Metapelite } \\
\hline $\begin{array}{l}\text { Biotite } \\
\text { Spinel } \\
\text { Plagioclase }\end{array}$ & $\begin{array}{l}\mathrm{Eas}_{36-42}, \mathrm{mg} \# 18-24 \\
\mathrm{Spl}_{3-6} \\
\mathrm{An}_{92-98}\end{array}$ & $\begin{array}{l}\mathrm{Eas}_{33-39}, \mathrm{mg} \# 23-24 \\
\mathrm{Spl}_{6-7} \\
\mathrm{An}_{100}\end{array}$ \\
\hline \multicolumn{3}{|c|}{ Zone I } \\
\hline $\begin{array}{l}\text { Biotite } \\
\text { Spinel } \\
\text { Plagioclase }\end{array}$ & $\begin{array}{l}\text { Eas }_{38-42}, \mathrm{mg} \# 23-24 \\
\mathrm{Spl}_{5-6} \\
\mathrm{An}_{92-98}\end{array}$ & $\begin{array}{l}\mathrm{Eas}_{20-30}, \mathrm{mg} \# 20-25 \\
\mathrm{Spl}_{4-7} \\
\mathrm{An}_{100}\end{array}$ \\
\hline \multicolumn{3}{|c|}{ Zone II } \\
\hline $\begin{array}{l}\text { Biotite } \\
\text { Spinel } \\
\text { Plagioclase }\end{array}$ & $\begin{array}{l}\mathrm{Eas}_{37-45}, \mathrm{mg} \# 29-36 \\
\mathrm{Spl}_{7-9} \\
\mathrm{An}_{95-98}\end{array}$ & $\begin{array}{l}\mathrm{Eas}_{25-35}, \mathrm{mg} \# 20-30 \\
\mathrm{Spl}_{4-11} \\
\mathrm{An}_{100}\end{array}$ \\
\hline \multicolumn{3}{|c|}{ Zone II } \\
\hline $\begin{array}{l}\text { Garnet } \\
\text { Biotite } \\
\text { Plagioclase }\end{array}$ & $\begin{array}{l}\mathrm{Alm}_{36-68} \mathrm{Grs}_{15-30} \operatorname{Prp}_{3-7} \\
\mathrm{Eas}_{20-42}, \mathrm{mg} \# 34-41 \\
\mathrm{An}_{95-97}\end{array}$ & $\begin{array}{l}\mathrm{Alm}_{53-64} \mathrm{Grs}_{31-42} \mathrm{Prps}_{5} \\
\mathrm{Eas}_{50}, \mathrm{mg} \# 25-40 \\
\mathrm{An}_{100}\end{array}$ \\
\hline \multicolumn{3}{|c|}{ Zone IV } \\
\hline $\begin{array}{l}\text { Garnet } \\
\text { Amphibole } \\
\text { Biotite } \\
\text { Plagioclase }\end{array}$ & $\begin{array}{l}\operatorname{Arm}_{54-59} \mathrm{Grs}_{25-33} \operatorname{Prp}_{5-6} \\
\operatorname{Prg}_{38-58} \mathrm{Ts}_{16-36} \mathrm{Tr}_{12-407} \text { mg } 31-37 \\
\mathrm{Eas}_{23-28}, \mathrm{mg} \# 41 \\
\mathrm{An}_{96-99}\end{array}$ & $\begin{array}{l}\mathrm{Alm}_{53-60} \mathrm{Grs}_{32-44} \operatorname{Prp}_{3-8} \\
\operatorname{Prg}_{55-60} \mathrm{Tr}_{40-45}, \mathrm{mg} \# 20-35 \\
\mathrm{Eas}_{40}, \mathrm{mg} \# \mathrm{25-35} \\
\mathrm{An}_{100}\end{array}$ \\
\hline \multicolumn{3}{|c|}{ Zones IV-V } \\
\hline $\begin{array}{l}\text { Amphibole } \\
\text { Biotite } \\
\text { Clinopyroxene } \\
\text { Plagioclase }\end{array}$ & $\begin{array}{l}\operatorname{Prg}_{36-58} \mathrm{Ts}_{16-36} \mathrm{Tr}_{12-40}, \mathrm{mg} \# 31-37 \\
\mathrm{Eas}_{23-28,} \mathrm{mg}^{\# 41} \\
\mathrm{Hd}_{46} \\
\mathrm{An}_{36-99}\end{array}$ & $\begin{array}{l}\operatorname{Prg}_{60} \mathrm{Tr}_{40,}, \mathrm{mg} \# 35-45 \\
\mathrm{Eas}_{40,} \text { mg\# } 30-40 \\
\mathrm{Hd}_{59-70} \\
\mathrm{An}_{100}\end{array}$ \\
\hline \multicolumn{3}{|c|}{ Zone VI - Marble } \\
\hline $\begin{array}{l}\text { Garnet } \\
\text { Amphibole } \\
\text { Biotite } \\
\text { Clinopyroxene } \\
\text { Plagioclase }\end{array}$ & $\begin{array}{l}\mathrm{Grs}_{49-65} \mathrm{Alm}_{23-34} \operatorname{Prp}_{0.6-2} \\
\operatorname{Prg}_{88-90} \mathrm{Ts}_{11-15}, \mathrm{mg} \# 29-31 \\
\text { Eas }_{29-32}, \mathrm{mg}_{3} 34 \\
\mathrm{Hd}_{44-67} \\
\mathrm{An}_{99}\end{array}$ & $\begin{array}{l}\mathrm{Grs}_{80} \text { Alm }_{20} \mathrm{Prp}_{0} \\
\text { Prg }_{100}, \mathrm{mg} \# 25-45 \\
\text { Eas }_{40}, \mathrm{mg} \# 20-40 \\
\mathrm{Hd}_{35-80} \\
\mathrm{An}_{100}\end{array}$ \\
\hline
\end{tabular}

Predicted composition of the phases in the shaded fields of Figures 6 and 8 . Mixing properties of the garnet solid-solution have been taken from Berman (1990). The remaining solid-solutions (biotite, clinopyroxene, amphibole, and hercynite) were modeled as being ideal, assuming site populations as in Holland \& Powell (1990). See text for details on the calculations. mg\#: $100^{*} \mathrm{Mg} /\left(\mathrm{Mg}+\mathrm{Fe}^{2+}\right)$. Mineral abbreviations after Kretz (1983).

(1990) (grossular, pyrope, and almandine endmembers).

The estimation of equilibrium conditions for the assemblages studied is made by comparing the predicted and the observed compositions for the minerals of interest (Connolly et al. 1994) (Table 3).

Four univariant reactions result for the system considered (Fig. 6), and define an invariant point at $715^{\circ} \mathrm{C}$ and 4.9 kbar. These univariant reactions (labeled using the phase-absent notation of Zen 1966) are: [Bt, Grt, Hc, An, Als]:

$$
\mathrm{Ms}=\mathrm{Crn}+\mathrm{Kfs}+\mathrm{H}_{2} \mathrm{O} \text {, }
$$

producing corundum at the expense of muscovite; reaction [Crn]:

$$
\mathrm{Ms}+\mathrm{Grt}+\mathrm{Bt}=\mathrm{An}+\mathrm{Kfs}+\mathrm{Hc}+\mathrm{Als}
$$

one of several possible hercynite-producing reactions that consumes muscovite, all of which run subparallel to reaction (1); reaction [Ms]:

$$
\mathrm{Grt}+\mathrm{Bt}+\mathrm{Crn}=\mathrm{Kfs}+\mathrm{An}+\mathrm{Hc}+\mathrm{Als},
$$

which consumes garnet toward lower-pressure conditions ( $\mathrm{P}<5-5.5 \mathrm{kbar}$ ), and finally, at temperatures below the corundum-forming reaction (1), there is another hercynite-forming reaction, [Kfs]:

$$
\mathrm{Bt}+\mathrm{Grt}+\mathrm{Crn}=\mathrm{Ms}+\mathrm{An}+\mathrm{Hc}+\mathrm{Als},
$$

which consumes corundum, biotite, and garnet toward lower-pressure conditions ( $\mathrm{P}<5$ to $3.5 \mathrm{kbar}$ ).

This topology could be affected by the occurrence of a certain amount of $\mathrm{CO}_{2}$ in the fluid phase during metamorphism, as suggested by the proximity of the marble to the metapelite. Nevertheless, for the calculated composition of the fluid phase in the marble $\left[0.11<X(\mathrm{CO})_{2}<0.16\right.$ : López Sánchez-Vizcaíno \& Soto 1999 ], reaction (1) is displaced to lower temperatures by about $10^{\circ} \mathrm{C}$ only (Fig. 6). As a result, we can henceforth use pure $\mathrm{H}_{2} \mathrm{O}$ as a valid approximation to the fluid composition as far as the $\mathrm{CO}_{2}$ content is concerned.

The appearance of corundum in coexistence with $\mathrm{K}$-feldspar in the metapelites from the basement on the Alborán Sea has been associated by Soto \& Platt (1999) with the breakdown reaction of muscovite in quartzabsent rocks, by means of the univariant reaction (1). This proposal is confirmed by the absence of primary muscovite in all corundum-bearing metapelites. Thus, reaction (1) represents the lower-temperature limit of the corundum-bearing assemblages (Fig. 6). Furthermore, as we have not observed corundum associated with muscovite, reaction (4) did not take place in these rocks and, consequently, conditions of the hercynite stability were limited by reactions (2) and (3). Accordingly, the observed assemblage of corundum + hercynite + biotite + anorthite is stable at temperatures above reaction (1) and at pressures below reaction (3) (i.e., $\mathrm{T}>$ $650^{\circ} \mathrm{C}$ and $\mathrm{P}<5.5 \mathrm{kbar}$ ), as demonstrated by the topology of the reactions described above (Fig. 6).

These P-T conditions are consistent with the metamorphic peak described in other high-grade metapelites from the Alborán Sea basement by Soto \& Platt (1999). These authors reconstructed a decompression $\mathrm{P}-\mathrm{T}$ path that crossed the muscovite-out reaction (1) at temperatures below the invariant point depicted in Figure 6 . As a consequence, and using these data, reaction (2) would produce the growth of hercynite + Al-silicate and the consumption of garnet. The lack of garnet in the metapelite toward Zone $\mathrm{I}$ is in accordance with this 
proposition. Nonetheless, the absence of Al-silicate in the proximity of the reaction zones, together with the inverse relationships between the modal abundance of hercynite and corundum in Zone I, cannot easily be explained by the reaction history deduced from the univariant reactions. The former problem can be resolved, at least in part, by considering the relations in the divariant field [Grt, Ms], enclosed by the univariant reactions [Bt, Grt, Hc, An, Als] (1) and [Ms] (3). Within this field, the high-variance reactions [Grt, Ms]:

$$
\mathrm{Bt}+\mathrm{Crn}+\mathrm{Als}=\mathrm{Bt}+\mathrm{Kfs}+\mathrm{Hc}
$$

and [Grt, Ms, Als]:

$$
\mathrm{Bt}+\mathrm{Crn}=\mathrm{Bt}+\mathrm{Kfs}+\mathrm{Hc},
$$

determine the consumption of Al-silicate and corundum, and the formation of hercynite and K-feldspar, with increasing temperature.

These reactions can more properly be interpreted as isopleths showing the change of the chemical composition of biotite and hercynite. Figure 6 shows how in the $\mathrm{P}-\mathrm{T}$ stability field of hercynite with a composition similar to that observed in the rocks $\left(\mathrm{spl}_{5}-\mathrm{spl}_{7}\right)$, the coexisting biotite has $\mathrm{mg \#}$ values ranging from 20 to 24 , whereas $X_{\text {eas }}$ increases toward lower temperatures (or higher pressures; dashed lines in Fig. 6). Also, sillimanite together with hercynite and biotite of the appropriate compositions (thin solid lines) coexist in a very narrow $\left(<10^{\circ} \mathrm{C}\right) \mathrm{P}-\mathrm{T}$ field, placed at temperatures immediately above the univariant reaction [1]. This reconstruction allows us to constrain the stability conditions of the assemblage observed (biotite, corundum, hercynite, anorthite, and $\mathrm{K}$-feldspar) to the narrow shaded field shown in Figure $6\left(\mathrm{P} \approx 4.3-5.1 \mathrm{kbar}, \mathrm{T} \approx 705-730^{\circ} \mathrm{C}\right)$. These were most probably the metamorphic conditions prevailing during the formation of the reaction zones, as is also demonstrated by the good correspondence between the observed and the predicted compositions of the minerals (Table 3 ).

In spite of this interpretation, the topology depicted in Figure 6 is insufficient to explain the lack of garnet and sillimanite in the corundum metapelite close to and in the reaction zones. As both minerals appear to be in textural equilibrium with corundum away from the reaction zones, the variation of other thermodynamic properties of the system must be invoked. The calculation of chemical potential projections at constant $\mathrm{P}$ and $\mathrm{T}$ could largely resolve these apparent inconsistencies, as we will discuss below.

\section{DeVelopment of the ReAction Zones}

\section{Origin of the Al-rich protoliths}

Although the association of rock types and the metamorphic characteristics of the basement sampled at Site
976 resemble those within parts of the Alpujárride Complex of the adjacent Betic Cordillera, corundum-bearing metapelites like those studied here have not yet been described in the onshore Alpujárride rocks ( $c f$. Westerhof 1975, Torres-Roldán 1979). Considering the petrological history of the basement in the Alborán Sea, the Al-enrichment in these metapelites could be driven by partial melting (see Osanai et al. 1998, and references therein). According to the $\mathrm{P}-\mathrm{T}$ evolution proposed by Soto \& Platt (1999), partial melting occurred under low-P conditions owing to the breakdown of muscovite, and would have produced the loss of $\mathrm{SiO}_{2}$ and the $\mathrm{Al}_{2} \mathrm{O}_{3}$ enrichment enhancing the former chemical gradient between the metapelite and the marble. The extent of melting is difficult to evaluate, but textural and mineralogical observations made by these authors suggest that this process was incipient in the high-grade schist rocks. Therefore, it is also possible that the observed Al-enrichment in some domains of the high-grade schist occurred only adjacent to layers originally poor in quartz.

\section{Evidence for diffusion}

The reaction zones described developed along the boundary between two contrasting rock-types, corundum-bearing metapelite and marble, and are interpreted as having been formed by diffusion-induced metasomatism during metamorphism. Several observations support this interpretation: 1) the symmetrical distribution of calc-silicate bands on both sides of the metapelite intercalations in the marble (López Sánchez-Vizcaíno $\&$ Soto 1999), and 2) the small scale of all observed reaction-zones ( $<3 \mathrm{~mm}$ in width). From these two observations, we can infer the existence of steep gradients in chemical potential between the reacting rocks. For these conditions, diffusion is a rapid process of transport (Bucher 1998), since the rate of diffusion is proportional to the chemical potential gradient and inversely proportional to the distance of transport (Bucher 1998, eq. 10). 3) The chemical variation of several minerals (garnet, biotite, hercynite; Figs. 5, 6) is continuous across the reaction bands (Korzhinskii 1970, Hofmann 1972). 4) The bulk and mineralogical compositions of the reaction zones are intermediate with respect to the bulk compositions of the reacting rocks (Dunkley et al. 1999), as revealed in an ACF projection (Fig. 7, Table 2).

\section{Chemical potential analysis of reaction zones}

Chemical potential projections of phase diagrams have frequently been used to study infiltration or diffusion zones with a simple mineralogy and chemical composition. Consequently, they are an important tool for the study of mass-transfer processes in geological environments (e.g., Korzhinskii 1959, 1965, Burt 1974, Brady 1977). In this paper, we calculate such projections at constant $\mathrm{P}-\mathrm{T}$ conditions, corresponding to the 


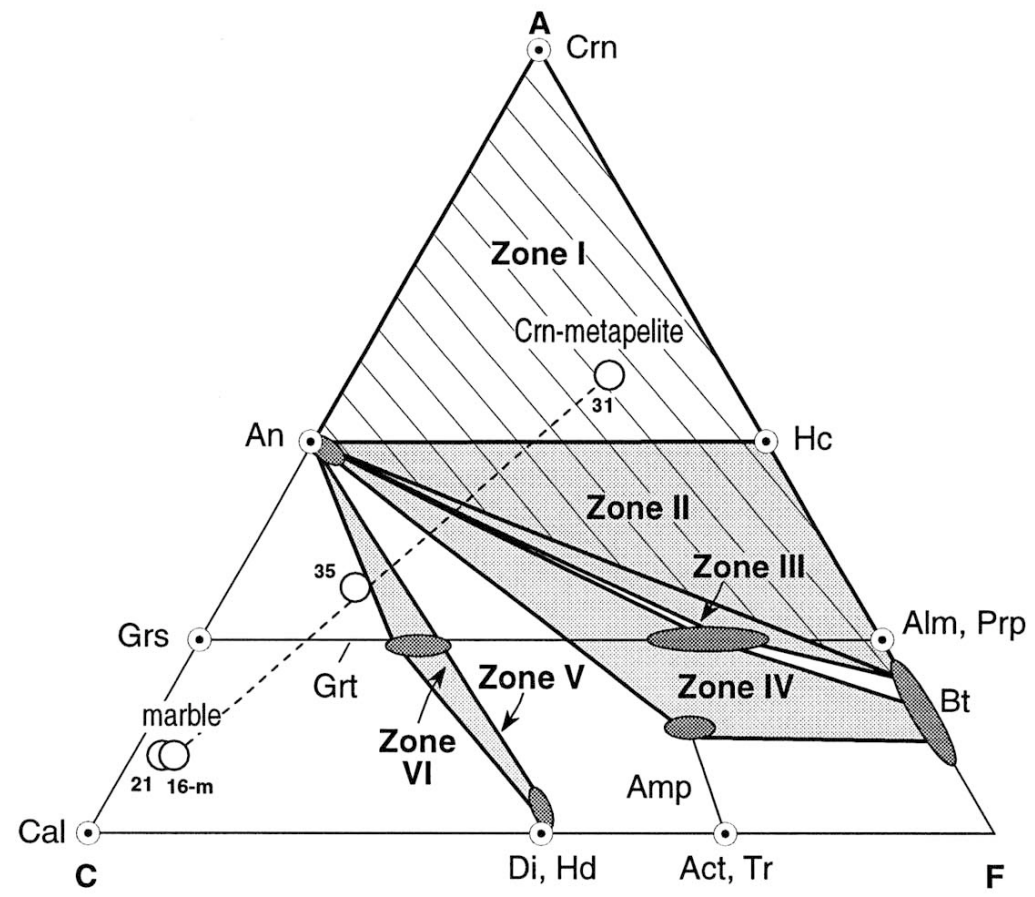

FIG. 7. ACF diagram with the mineral assemblages for the reaction zones, the corundum bearing-metapelite, and the impure calcite-dominant marble. The hatched area represents the Crn metapelite and zone I. Dark grey fields represent the chemical composition of minerals from reaction zones (sample 976B-76R-1, piece 9a, 75-79 $\mathrm{cm}$ ). Open circles correspond to bulk-rock compositions (Table 3) of impure calcite marbles (sample 16-m: 976E-17R-2, 31-35 cm, and sample 21: 976E-13R-3, 12-15 $\mathrm{cm}$ ), corundum-bearing metapelite (sample 31: 976B-77R-2, 40-44 cm), and from a clinopyroxene + anorthite + garnet reaction zone (sample 35: 976B-76R-2, 111-114 cm). A: $\mathrm{Al}_{2} \mathrm{O}_{3}+\mathrm{Fe}_{2} \mathrm{O}_{3}$; $\mathrm{C}: \mathrm{CaO} ; \mathrm{F}: \mathrm{FeO}+\mathrm{MgO}$.

diffusion-induced processes of mass transfer involved in the origin of the reaction zones.

Although many reaction zones between metapelites and calcite marbles have been essentially explained by the diffusion of $\mathrm{CaO}$ (e.g., Thompson 1975, Glassley 1983), the occurrence of corundum in the metapelites and of distinct silicate minerals in all reaction zones in our suite suggests that diffusion of $\mathrm{Al}_{2} \mathrm{O}_{3}$ and $\mathrm{SiO}_{2}$ could also have a significant influence in the formation of the reaction zones. Other likely diffusing components, as for example $\mathrm{FeO}$ and $\mathrm{MgO}$, have not been incorporated in the model since they would have had a minor influence on the formation of the reaction zones, as is deduced from the ACF diagram (Fig. 7). Therefore, we analyzed the formation of the reaction zones by means of the variations in the chemical potentials of $\mathrm{CaO}$, $\mathrm{Al}_{2} \mathrm{O}_{3}$ and $\mathrm{SiO}_{2}$ in the phase diagram projections $\mu_{\mathrm{CaO}}$ $-\mu_{\mathrm{SiO} 2}$ and $\mu_{\mathrm{CaO}}-\mu_{\mathrm{Al} 2 \mathrm{O} 3}$ (Figs. 8a, b). The $\mu_{\mathrm{Al} 2 \mathrm{O} 3}-$ $\mu_{\mathrm{SiO} 2}$ projection was also calculated, but it does not give important additional information.
In accordance with the inferred field of stability for the corundum-bearing assemblage in the model P-T diagram (Fig. 6), the P-T conditions chosen for the calculations are $725^{\circ} \mathrm{C}$ and $5 \mathrm{kbar}$. Phase relations have been calculated for the chemical system $\mathrm{FeO}-\mathrm{MgO}-$ $\mathrm{SiO}_{2}-\mathrm{Al}_{2} \mathrm{O}_{3}-\mathrm{CaO}-\mathrm{Na}_{2} \mathrm{O}-\mathrm{K}_{2} \mathrm{O}-\mathrm{H}_{2} \mathrm{O}$ using all of the minerals observed in the reaction zones. Phase relations including calcite, and consequently $\mathrm{CO}_{2}$, have been calculated independently, although the results are shown superposed onto the other diagrams (Fig. 8). The calculations have been made with Vertex (Connolly 1990) using the same solid-solution models and database as referred to previously. Ideal solid-solution models for amphibole (tremolite, actinolite, tschermakite, ferrotschermakite, pargasite, ferropargasite) and clinopyroxene (diopside-hedenbergite) also have been included.

The results obtained are summarized in Figure 8 and in Table 3, where a comparison is made between the calculated and the observed compositions of minerals. 
In both the $\mu_{\mathrm{CaO}}-\mu_{\mathrm{Al} 2 \mathrm{O} 3}$ and $\mu_{\mathrm{CaO}}-\mu_{\mathrm{SiO} 2}$ projections, the general pattern is depicted for the different fields of stability according to the reaction zones observed from the corundum-bearing metapelite to the calcite marble. In the $\mu_{\mathrm{CaO}}-\mu_{\mathrm{A} 12 \mathrm{O} 3}$ projection, the stability of corundum has been calculated at $\mu_{\mathrm{Al} 2 \mathrm{O} 3} \approx-0.1656 * 10^{7} \mathrm{~J}$ for the above-mentioned P-T conditions $\left(725^{\circ} \mathrm{C}\right.$ and 5 kbar). Similarly, the stability of quartz has been calculated in the $\mu_{\mathrm{CaO}}-\mu_{\mathrm{SiO} 2}$ projection at $\mu_{\mathrm{SiO} 2} \approx-0.9024$ $* 10^{6} \mathrm{~J}$.

To overcome the problem of the high variance of the mineral assemblages in several reaction-zones, we have applied, where necessary, the principle of local equilibrium to the contact between two consecutive reactionzones (Thompson 1959). We calculated the stability conditions for the combination of both mineral assemblages. Note that the stability conditions of the corundum-bearing metapelite could not be shown in these diagrams owing to its very high variance.

In Figure 8a, the stability conditions of Zone I plot over the $\mathrm{Crn}$ line (equivalent to the $\mathrm{Crn}=\mathrm{An}$ reaction in Fig. 8 b) in a region where corundum coexists with hercynite and biotite of the observed chemical composition (Table 3). The two diagrams also show that, at the P-T conditions estimated in Figure 6 , the $\mu_{\mathrm{SiO}_{2}-}$ $\mu_{\mathrm{CaO}}-\mu_{\mathrm{Al} 2 \mathrm{O} 3}$ stability conditions of Zone I are incompatible with the occurrence of sillimanite and garnet. Besides, it is also apparent that the disappearance of corundum from Zone I toward Zone II, difficult to explain owing to $\mathrm{P}-\mathrm{T}$ variations (see above), was also a diffusion-driven process induced by gradients in chemical potential. Zone II is stable in the field defined by several divariant reactions involving anorthite, biotite and hercynite. Such reactions fit the observed enrichment in $\mathrm{Mg}$ of hercynite and in $\mathrm{Mg}$ and Tschermak substitution (eastonite component) of biotite toward Zone III, in which garnet appears. These mineralogical and compositional changes take place throughout an increase of $\mu_{\mathrm{CaO}} \approx 0.15 * 10^{6} \mathrm{~J}$, a decrease of $\mu_{\mathrm{Al2O} 3} \approx 9$ $* 10^{4} \mathrm{~J}$ and nearly constant $\mu_{\mathrm{SiO} 2}$.

Owing to the heterogeneous distribution of minerals (garnet, biotite and amphibole) in Zone IV, calculations were made using the observed compositions of coexisting garnet, biotite, and amphibole (field IV in Fig. 8), as well as the assemblage in the contact between zones IV and V, namely: amphibole, biotite, clinopyroxene, and anorthite. There is, in general, a good correlation between the observed and the calculated compositions for the various minerals (Table 3 ), but only the tschermakite content of amphibole differs substantially from the observed values. However the described mineralogical changes between zones III and V occurred with slightly decreasing values of $\mu_{\mathrm{CaO}}\left(\approx-0.740 * 10^{6} \mathrm{~J}\right.$ on average), through a decrease of $\mu_{\mathrm{Al} 2 \mathrm{O} 3} \approx 9 * 10^{4} \mathrm{~J}$ and in increase of $\mu_{\mathrm{SiO} 2} \approx 5 * 10^{3} \mathrm{~J}$.

Finally, the stability field of the low-variance assemblage found in the contact between Zone VI and the marble has been calculated in separate diagrams. The calculation was made with the previously described solid-solutions, together with a pargasitic amphibole composition (ideal solid-solution between pargasite and ferropargasite) and a fluid phase with a composition ranging between pure $\mathrm{H}_{2} \mathrm{O}$ and $\mathrm{CO}_{2}$. The calculated phase-relationships, superposed on Figure 8, demonstrate that the observed assemblage was only stable at $\mathrm{CO}_{2}$-poor fluid compositions $\left[X\left(\mathrm{CO}_{2}\right)<0.15\right]$. This inference agrees with previous calculations of the fluid composition in the marbles (López Sánchez-Vizcaíno \& Soto 1999) and validates the assumption of a pure $\mathrm{H}_{2} \mathrm{O}$ fluid in all of the calculations made. The transition from the fields IV-V to VI-M took place through a significant increase in $\mu_{\mathrm{CaO}} \approx 1 * 10^{4} \mathrm{~J}$, a decrease in $\mu_{\mathrm{SiO} 2}$ $\approx 4 * 10^{3} \mathrm{~J}$ and almost constant $\mu_{\mathrm{Al} 2 \mathrm{O} 3}$.

In summary, the deduced fields of stability of the different assemblages in terms of chemical potentials depict a possible general path of change in $\mu_{\mathrm{CaO}}, \mu_{\mathrm{Al} 2 \mathrm{O} 3}$, and $\mu_{\mathrm{SiO} 2}$. This path is in agreement with the expected variation from an Al-saturated metapelite to a calcite marble; nonetheless, it is far from the continuous monotonic gradients in the chemical potential of the diffusing components considered in the ideal models dealing with the study of these processes (Brady 1977). In fact, three distinctive segments with very different slopes can be distinguished in the diagrams (Figs. 8a, b). The main inflexion along the path corresponds to the transition from zone III to zone IV. This inflexion probably reflects the heterogeneous nature of the protolith in these zones, which may derive partly from a corundum metapelite and partly from a quartz-bearing metapelite (Fig. 2a).

\section{Discussion OF THE Model}

There is general agreement that the continuous change in the chemical composition of the minerals is one of the outstanding features of diffusion zones (Korzhinskii 1970, Brady 1977), but in most cases, chemical potential diagrams are constructed considering that the minerals involved are pure substances (Brady 1977). This approach impedes, inevitably, the calculation of continuous reactions and may lead to uncertainties in the results obtained. The model developed here, however, explains satisfactorily the sequence of mineral assemblages observed as well as the change in the chemical composition of most of the minerals (garnet, biotite, clinopyroxene and spinel).

In spite of this, the proposed model also displays several limitations. For example, it is impossible to explain some features, namely, the irregular distribution of zones I, II, and III, the variable thickness of some bands (see Fig. 3), and the variation in the modal abundance of some minerals within certain zones, such as, for example, corundum in zone I, hercynite in zone II, and biotite and amphibole in zone IV. All these features point to the formation of these reaction zones under nonideal conditions. Variable rates of reaction and cation 


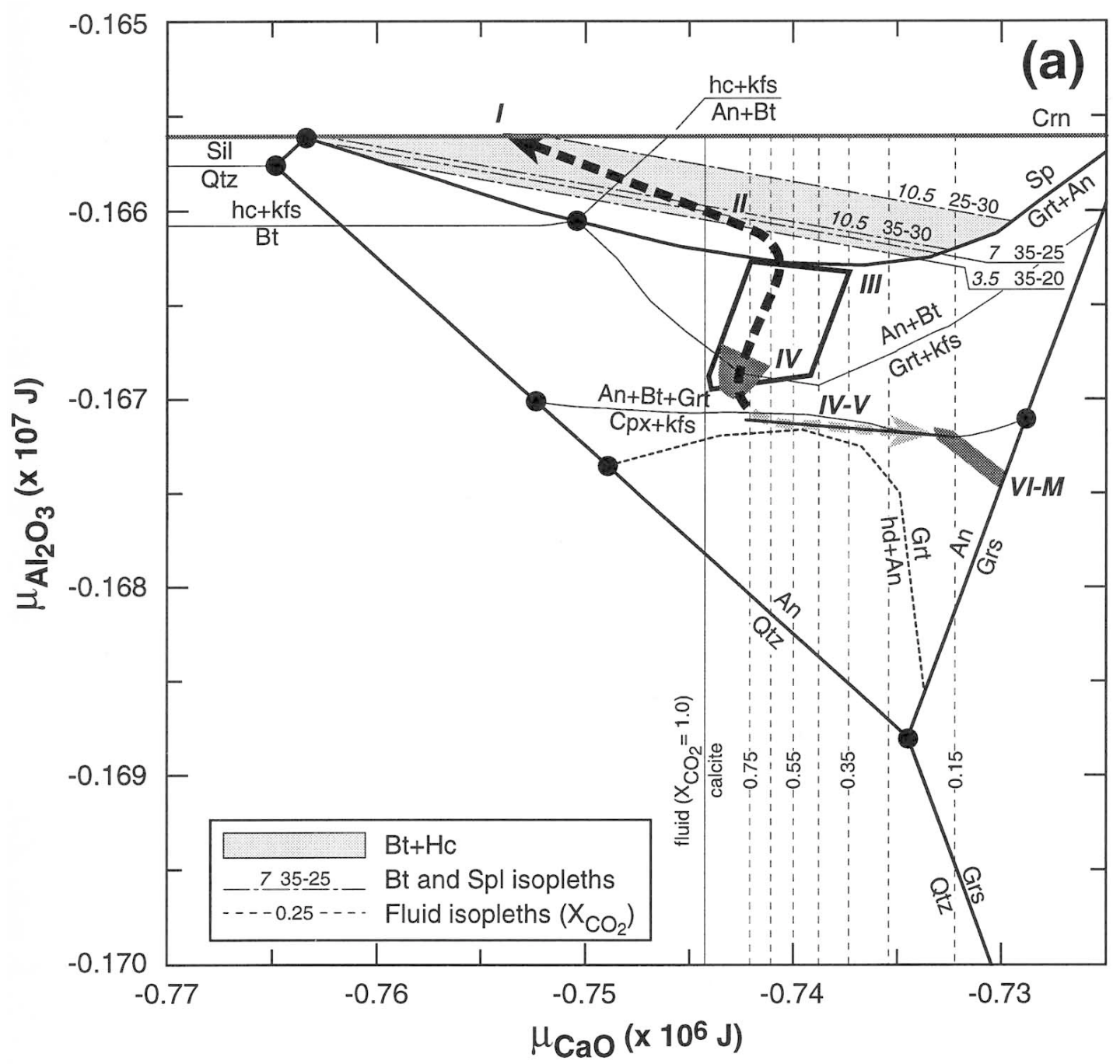

FIG. 8. (a) $\mu_{\mathrm{CaO}}-\mu_{\mathrm{Al} 2 \mathrm{O} 3}$ diagram calculated for the corundum-bearing metapelite and for the reaction zones (stability fields in dark shading) in the system $\mathrm{K}_{2} \mathrm{O}-\mathrm{Na}_{2} \mathrm{O}-\mathrm{CaO}-\mathrm{FeO}-\mathrm{MgO}-\mathrm{Al}_{2} \mathrm{O}_{3}-\mathrm{SiO}_{2}$, after projection through $\mathrm{H}_{2} \mathrm{O}$, at constant $\mathrm{T}=725^{\circ} \mathrm{C}$ and $\mathrm{P}=5 \mathrm{kbar}$. Thick broken line with arrows shows the deduced variation of both chemical potentials to explain the formation of the reaction zones (see text for details). All the curves are univariant reactions, and the phases involved have been omitted except in the most important cases. Circles are invariant points. The thick grey line represents the saturation conditions of corundum. Labels in the Bt and Spl isopleths correspond, like in Figure 6, to the spinel content of hercynite and to the eastonite content and $\mathrm{mg} \#$ of biotite, respectively. (b) $\mu_{\mathrm{CaO}}-\mu_{\mathrm{SiO} 2}$ diagram showing the stability conditions for the observed assemblages and mineral compositions (see Table 3). The thick grey line represents the saturation conditions of quartz. Same conditions and notation as in Figure 8a.

exchange between coexisting minerals could exert some influence (Dunkley et al. 1999). According to Brady (1977), it is also very possible that the components diffusing in the reaction zones $\left(\mathrm{CaO}, \mathrm{Al}_{2} \mathrm{O}_{3}\right.$, and $\left.\mathrm{SiO}_{2}\right)$ could have different velocities of diffusion and density in the intergranular region. In that case, diffusion of one component would produce gradients in the chemical potential of the other components, and the sequence of reaction zones inferred in the chemical potential diagram will not be a straight line (Brady 1977).

Although this situation probably occurred in our case, it is evident that the main complications in the calculated path of chemical potentials unavoidably result from the heterogeneous character of some of the 


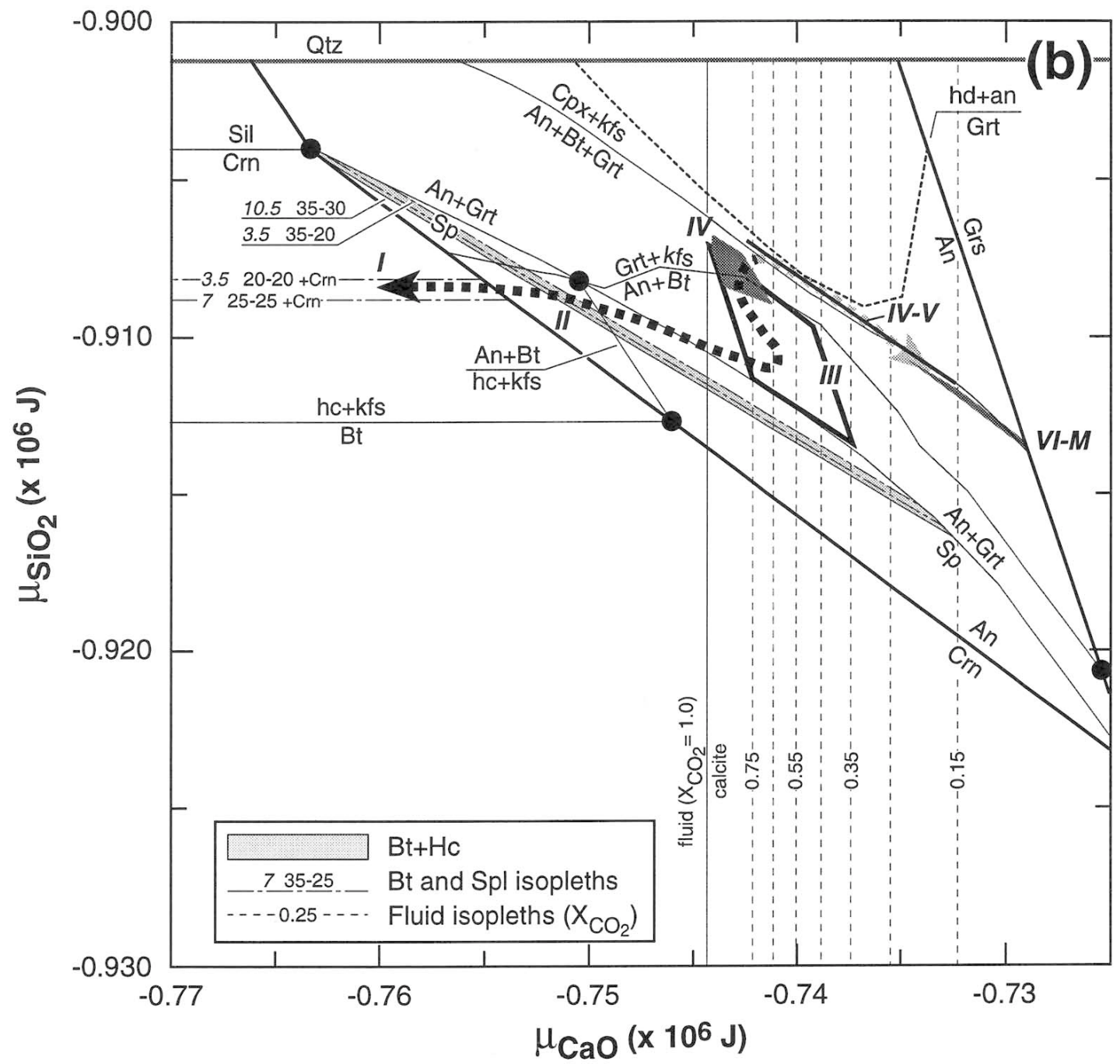

reaction zones (e.g., zone III). This would explain the observed sharp increase in the chemical potential of silica and the sharp decrease in that of alumina at the front between zone II (derived from a corundum-bearing pelite) and zone III (partly derived from a quartzbearing pelite).

In conclusion, these reaction zones seem to result from the existence of important chemical gradients in the Alborán Sea basement, probably enhanced by incongruent melting accompanying muscovite dehydration. The P-T conditions deduced for the development of the reaction zones $(4.3<\mathrm{P}<5.1 \mathrm{kbar}, 705<\mathrm{T}<$ $730^{\circ} \mathrm{C}$ ) are consistent with the metamorphic evolution of the Alborán Sea basement, characterized by a peak temperature achieved at low-P conditions (Soto \& Platt 1999).

\section{ACKNOWLEDGEMENTS}

Project MAR98-0981-CICYT together with Grupo de Investigación 4019 (Junta de Andalucía) provided the financial support for this work. Project BTE2000-1489 and Grupo RNM-0145 are acknowledged as well. We thank M.F. Taner, an anonymous reviewer, and R.F. Martin for their constructive criticism and suggestions, and J.A.D. Connolly for his critical reading of a previous version of the manuscript. We also thank Chris Laurin for her corrections of the English version of the manuscript.

\section{REFERENCES}

Berman, R.G. (1990): Mixing properties of Ca-Mg-Fe-Mn garnets. Am. Mineral. 75, 328-344. 
BRADY, J.B. (1977): Metasomatic zones in metamorphic rocks Geochim. Cosmochim. Acta 41, 113-125.

BUCHER, K. (1998): Growth mechanisms of metasomatic reaction veins in dolomite marbles from the Bergell Alps. Mineral. Petrol. 63, 151-171.

BurT, D.M. (1974): Metasomatic zoning in $\mathrm{Ca}-\mathrm{Fe}-\mathrm{Si}$ exoskarns. In Geochemical Transport and Kinetics (A.W. Hofmann, B.J. Giletti, H.S. Yoder, Jr. \& R.A. Yund, eds.). Carnegie Inst. Washington, Publ. 634, 287-293.

Comas, M.C., García-Dueñas, V. \& JuRado, M.J. (1992): Neogene tectonic evolution of the Alboran Sea from MCS data. Geo-Marine Lett. 12, 157-164.

ConNolly, J.A.D. (1990): Multivariable phase diagrams: an algorithm based on generalized thermodynamics. Am. J. Sci. 290, 666-718.

Memmi, I., TrommsdorfF, V., Franceschelli, M. \& RicCI, C.A. (1994): Forward modelling of calc-silicate microinclusions and fluid evolution in a graphitic metapelite (northeast Sardinia). Am. Mineral. 79, 960-972.

Dunkley, D.J., Clarke, G.L. \& Harley, S.L. (1999): Diffusion metasomatism in silica-undersaturated sapphirine-bearing granulite from Rumdoodle Peak, Frammes Mountains, east Antarctica. Contrib. Mineral. Petrol. 134, 264-276.

FISHER, G.W. (1989): Matrix analysis of metamorphic mineral assemblages and reactions. Contrib. Mineral. Petrol. 102, 69-77.

(1993): An improved method for algebraic analysis of metamorphic mineral assemblages Am. Mineral. 78, $1257-1261$.

GLASSLEY, W.E. (1983): Deep crustal carbonates as $\mathrm{CO}_{2}$ fluid sources: evidence from metasomatic reaction zones. Contrib. Mineral. Petrol. 84, 15-24.

Hofmann, A. (1972): Chromatographic theory of infiltration metasomatism and its application to feldspars. Am. J. Sci. 272, 69-90.

Holland, T.J.B. \& Powell, R. (1990): An enlarged and updated internally consistent thermodynamic dataset with uncertainties and correlations: the system $\mathrm{K}_{2} \mathrm{O}-\mathrm{Na}_{2} \mathrm{O}-$ $\mathrm{CaO}-\mathrm{MgO}-\mathrm{MnO}-\mathrm{FeO}-\mathrm{Fe}_{2} \mathrm{O}_{3}-\mathrm{Al}_{2} \mathrm{O}_{3}-\mathrm{TiO}_{2}-\mathrm{SiO}_{2}-\mathrm{C}-\mathrm{H}_{2}-$ $\mathrm{O}_{2}$. J. Metamorph. Geol. 8, 89-124.

$\&$

(1991): A compensated-RedlichKwong (CORK) equation for volumes and fugacities of $\mathrm{CO}_{2}$ and $\mathrm{H}_{2} \mathrm{O}$ in the range 1 bar to $50 \mathrm{kbar}$ and 100 $1600^{\circ}$ C. Contrib. Mineral. Petrol. 109, 265-273.

JOESTEN, R. (1977): Evolution of mineral assemblage zoning in diffusion metasomatism. Geochim. Cosmochim. Acta 41, 649-670.

(1991): Local equilibrium in metasomatic processes revisited: diffusion-controlled growth of chert nodule reaction rims in dolomite. Am. Mineral. 76, 743-755.
KERRICK, D.M. (1977): The genesis of zoned skarns in the Sierra Nevada, California. J. Petrol. 18, 144-181.

KoRZHINSKII, D.S. (1959): Physicochemical Basis of the Analysis of the Paragenesis of Minerals. Consultants Bureau, Inc. New York, N.Y.

(1965): The theory of systems with perfectly mobile components and processes of mineral formation. Am. J. Sci. 263, 193-205.

(1970): Theory of metasomatic zoning. Clarendon Press, Oxford, U.K.

KretZ, R. (1983): Symbols for rock-forming minerals. Am. Mineral. 68, 277-279.

LeAKe, B.E., Woolley, A.R., Arps, C.E.S., Birch, W.D., GILBert, M.C, Grice, J.D., Hawthorne, F.C., Kato, A., Kisch, H.J., KrivovicheV, V.G., Linthout, K., LAIRD, J., Mandarino, J.A., Maresch, W.V., Nickel, E.H., Rock, N.M.S., Schumacher, J.C., Smith, D.C., Stephenson, N.C.N., Ungaretti, L., WhitTAKer, E.J.W. \& Youzhi, G. (1997): Nomenclature of amphiboles: report of the Subcomittee on Amphiboles of the International Mineralogical Association, Commission on New Minerals and Minerals Names. Can. Mineral. 35, 219-246.

LóPEZ SÁnCHEZ-VizCAÍNO, V. \& Soto, J.I. (1999): Metamorphism of calc-silicate rocks from the Alborán basement (Site 976). In Proc. ODP, Scientific Results 161 (R. Zahn, M.C. Comas \& A. Klaus, eds.). Ocean Drilling Program, College Station, Texas (251-261).

Osanai, Y., Hamamoto, T., Maishima, O. \& Kagami, H. (1998): Saphirine-bearing granulites and related high-temperature metamorphic rocks from the Higo metamorphic terrane, west-central Kyushu, Japan. J. Metamorph. Geol. 16, 53-66.

Platt, J.P., Soto, J.I., Whitehouse, M.J., Hurford, A.J. \& Kelley, S.P. (1998): Thermal evolution, rate of exhumation, and tectonic significance of metamorphic rocks from the floor of the Alboran extensional basin, western Mediterranean. Tectonics 17, 671-689.

Pouchou, J.-L., \& PICHOIR, F. (1985): PAP $\phi(\rho z)$ procedure for improved quantitative microanalysis. In Microbeam Analysis (J.T. Armstrong, ed.). San Francisco Press Inc., San Francisco, California.

Rieder, M., Cavazzini, G., D'Yakonov, Y.S., FrankKamenetskit, V.A., Gottardi, G., Guggenheim, S., Koval., P.V., Müller, G., Neiva, A.M.R., Radoslovich, E.W., Robert, J.L., SASSI, F.P., TAKedA, H., WeISS, Z. \& Wones, D.R. (1998): Nomenclature of the micas. Can. Mineral. 36, 905-912.

Shipboard Scientific Party (1996): Site 976. In Proc. ODP, Initial Reports 161 (M.C. Comas, R. Zahn, A. Klaus et al., eds.). Ocean Drilling Program, College Station, Texas (179-297). 
Soto, J.I. \& Platt, J.P. (1999): Petrological and structural evolution of high-grade metamorphic rocks from the floor of the Alboran Sea basin, western Mediterranean. J. Petrol. 40, 21-60.

SÁNCHEZ-GómEZ, M. \& AZAÑóN, J.M. (1999): Pressure-temperature evolution of the metamorphic basement of the Alboran Sea (Site 976) based on thermobarometry and structural observations. In Proc. ODP, Initial Reports 161 (M.C. Comas, R. Zahn, A. Klaus et al., eds.). Ocean Drilling Program, College Station, Texas (263-279).

Thompson, A.B. (1975): Calc-silicate diffusion zones between marble and pelitic schist. J. Petrol. 16, 314-346.

Thompson, J.B., JR. (1959): Local equilibrium in metasomatic processes. In Researches in Geochemistry (P.H. Abelson, ed.). John Wiley \& Sons, New York, N.Y. (427-457).

TORRES-RoldÁn, R.L. (1979): La evolución tectonometamórfica del macizo de los Reales (extremo occidental de la zona Bética). Ph.D. thesis, Univ. Granada, Granada, Spain.

, García-CASCO, A. \& GarCÍA-SÁNChEZ, P.A. (2000): CSpace: an integrated workplace for the graphical and algebraic analysis of phase assemblages on 32-bit wintel platforms. Comput. Geosci. 26, 779-793.

VAn Marcke de Lummen, G. \& Verkaeren, J. (1986): Physicochemical study of skarn formation in pelitic rock, Costabonne peak area, eastern Pyrenees, France. Contrib. Mineral. Petrol. 93, 77-88.

Westerhof, A.B. (1975): Genesis of magnetite ore near Marbella, southern Spain: formation by oxidation of silicates in polymetamorphic gedrite-bearing and other rocks. GUA Papers of Geology (Amsterdam), Ser. 1, no. 6.

Wood, B.J. \& BANNo, S. (1973): Garnet-orthopyroxene and orthopyroxene-clinopyroxene relationships in simple and complex systems. Contrib. Mineral. Petrol. 42, 109-124.

ZEN, E-AN (1966): Construction of pressure-temperature diagrams for multi-component systems after the method of Schreinemakers - a geometric approach. U.S. Geol. Surv., Bull. 1225.

Received August 8, 2001, revised manuscript accepted November 22, 2001. 